Special Section: Lysimeters in Vadose Zone Research

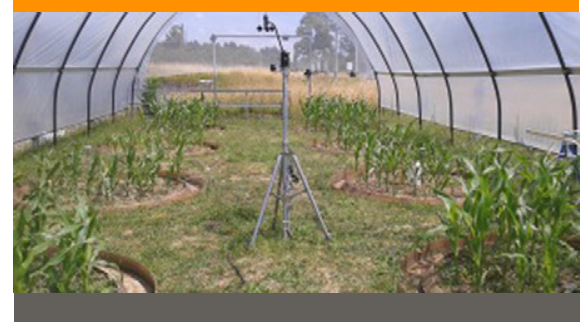

Core Ideas

- Atrazine preferential flow shortly after application was governed by soil type.

- Injection of atrazine at depth

enhanced preferential flow.

- Uranine realistically illustrated the

rapid and significant atrazine

breakthrough.

- In reserve, bromide mimicked early

atrazine breakthrough only with

moraine soil.

- Using dye tracers as pesticide

surrogates might assist in making

sustainable decisions.

C. Torrentó, V. Ponsin, and D. Hunkele

Centre for Hydrogeology and Geo-

thermics (CHYN), Univ. of Neuchâtel,

2000 Neuchâtel, Switzerland; V.

Prasuhn and E. Spiess, Agroscope,

Research Division, Agroecology and

Environment, 8046 Zürich, Switzerland;

A. Melsbach, C. Lihl, and M. Elsner,

Institute of Groundwater Ecology,

Helmholtz Zentrum München, 85764

Neuherberg, Germany; M. Elsner,

Analytical Chemistry and Water Che-

mistry, Technical Univ. of Munich,

D-81377 Munich, Germany; G. Glau-

ser, Neuchâtel Platform of Analytical

Chemistry, Univ. of Neuchâtel, 2000

Neuchâtel, Switzerland; T.B. Hofstetter,

Eawag, Swiss Federal Institute of Aqua-

tic Science and Technology, 8600

Dübendorf, Switzerland. *Correspon-

ding author (clara.torrento@unine.ch).

Received 31 Jan. 2017.

Accepted 18 May 2017.

Supplemental material online.

Citation: Torrentó, C., V. Prasuhn, E. Spiess V. Ponsin, A. Melsbach, C. Lihl, G. Glauser, T.B. Hofstetter, M. Elsner, and D. Hunkeler. 2018. Adsorbing vs. nonadsorbing tracers for assessing pesticide transport in arable soils. Vadose Zone J. 17:170033. doi:10.2136/vzj2017.01.0033

(c) Soil Science Society of America. This is an open access article distributed under the CC BY-NC-ND license (http://creativecommons.org/licenses/by-nc-nd/4.0/).

\section{Adsorbing vs. Nonadsorbing Tracers for Assessing Pesticide Transport in Arable Soils}

\author{
Clara Torrentó,* Volker Prasuhn, Ernst Spiess, Violaine \\ Ponsin, Aileen Melsbach, Christina Lihl, Gaétan Glauser, \\ Thomas B. Hofstetter, Martin Elsner, and Daniel Hunkeler
}

The suitability of two different tracers to mimic the behavior of pesticides in agricultural soils and to evidence the potential for preferential flow was evaluated in outdoor lysimeter experiments. The herbicide atrazine [6-chloro$\mathrm{N}$-ethyl-N'-(1-methylethyl)-1,3,5-triazine-2,4-diamine] was used as a model compound. Two tracers were used: a nonadsorbing tracer (bromide) and a weakly adsorbing dye tracer (uranine). Two soils that are expected to show a different extent of macropore preferential flow were used: a well-drained sandy-loamy Cambisol (gravel soil) and a poorly drained loamy Cambisol (moraine soil). Conditions for preferential flow were promoted by applying heavy simulated rainfall shortly after pesticide application. In some of the experiments, preferential flow was also artificially simulated by injecting the solutes through a narrow tube below the root zone. With depth injection, preferential leaching of atrazine occurred shortly after application in both soil types, whereas with surface application, it occurred only in the moraine soil. Thereafter, atrazine transport was mainly through the porous soil matrix, although contributions of preferential flow were also observed. For all the application approaches and soil types, after $900 \mathrm{~d},<3 \%$ of the applied amount of atrazine was recovered in the drainage water. Only uranine realistically illustrated the early atrazine breakthrough by transport through preferential flow. Uranine broke through during the first intense irrigation at the same time as atrazine. Bromide, however, appeared earlier than atrazine in some cases. The use of dye tracers as pesticide surrogates might assist in making sustainable decisions with respect to pesticide application timing relative to rainfall or soil potential for preferential flow.

Abbreviations: DAR, desethylatrazine/atrazine molar ratio; DEA, desethylatrazine; DIA, desisopropylatrazine; ET, evapotranspiration.

Herbicides are extensively used in agriculture for the protection of plants against weeds. Subsequently, the potential exists for leaching of these active substances and their metabolites to groundwater. Indeed, pesticides and their degradation products are frequently detected in groundwater (Leistra and Boesten, 1989; Kolpin et al., 1998, 2000; Loos et al., 2010; Lopez et al., 2015).

After application, the dissolved part of the herbicide that is neither taken up by plants nor carried with runoff to surface water moves downward and percolates through the soil profile into groundwater. The flow of water and solutes through soil is largely determined by the size and connectivity of the water-filled pores (Jarvis, 2007). In addition to transport through the porous matrix, pesticides may be rapidly leached below the root zone by advective transport through macropores (e.g., cracks, earthworm channels, root holes, fissures, and interaggregate packing voids), largely bypassing the soil matrix (Bouma and Dekker, 1978; Beven and Germann, 1982; Jarvis, 2007), reducing the potential for pollutant adsorption and degradation and thus increasing the threat of groundwater contamination (Kördel et al., 2008). This preferential flow is recognized as prevalent under a wide range of conditions in soils with unstable, poor structure as well as those containing cracks 
and channels (Flury et al., 1994). The potential for preferential flow is generally large for structured loamy and clayey soils containing large interaggregate pores. Pesticide losses resulting from macropore flow are typically $<1 \%$ of the applied dose, but losses of between 1 and 5\% may also occur (Jarvis, 2007). Leaching of as little as $0.1 \%$ of an applied pesticide may result in contaminant concentrations in shallow groundwater that already exceed the EU drinking water standard $\left(<0.1 \mu \mathrm{g} \mathrm{L}^{-1}\right)$ (Jarvis, 2007).

Degradation processes and sorption of solutes to soil particles can mitigate pesticide migration through the soil matrix. Degradation is governed by both abiotic and biotic factors, and degradation rates depend on many microbiological, physical, and chemical properties of the soil as well as the properties of the pesticide (Fenner et al., 2013). Once in the body of the soil, pesticide molecules partition between the aqueous and solid phases of the soil. The level of sorption is a function of the pesticide and the organic matter content of the soil (Wauchope et al., 2002). Physical entrapment within the soil solid phase and covalent bonding to soil organic matter or the clay mineral fraction of the soil might give rise to the so-called bound pesticide residues (Gevao et al., 2000). With longer residence times in the soil, these residues tend to lose their biological activity and become even more resistant to degradation (Calderbank, 1989). Bound residues of the herbicide atrazine corresponding to 9 and $25 \%$ of the applied amount have been found 9 and $22 \mathrm{yr}$ after application, respectively (Capriel et al., 1985; Jablonowski et al., 2008). Jablonowski et al. (2009) and Vonberg et al. (2014) found up to 1.0 and $0.2 \mu \mathrm{g} \mathrm{kg}^{-1}$ atrazine, respectively, in the topsoil $>20 \mathrm{yr}$ after the last application. A number of studies have observed a soil-bound residue fraction of other pesticides such as ethidimuron ( $N$-[5-(ethylsulfonyl)1,3,4-thiadiazol-2-yl]- $N, N^{\prime}$-dimethylurea), methabenzthiazuron ( $N$-2-benzothiazolyl- $N, N^{\prime}$-dimethylurea), anilazine [4,6-dichloro$N$-(2-chlorophenyl)-1,3,5-triazin-2-amine] (Jablonowski et al., 2012), and chloridazon [5-amino-4-chloro-2-phenyl-3(2H)-pyridazinone] (Schuhmann et al., 2016). However, even long-term immobilized compounds may be accessible to degradation by microorganisms (Jablonowski et al., 2008) and may also be released back to the soil solution. Long-term leaching of both extractable and bound pesticide residues, as well as metabolites, might occur as a result of changing environmental conditions in the soil (Gevao et al., 2000). Although the environmental risk posed by bound pesticide residues is considered to be low (Barraclough et al., 2005), leaching of extractable pesticide residues and microbial transformation of bound residues to mobile metabolites may represent a potential risk for groundwater contamination.

Strongly sorbing dye tracers have been used for identifying active flow paths and transport mechanisms in the vadose zone (Flury and Wai, 2003, and references therein). For marking preferential flow paths, many studies have applied a sorbing dye at the soil surface, excavated the soil profile after a specific infiltration time, and analyzed the dye distribution visually or using a computer software for photo interpretation (e.g., Flury and Wai, 2003, and references therein; Kasteel et al., 2005; Wang and Zhang, 2011; Kodešová et al., 2012). Brilliant Blue FCF is the most prominent dye tracer in vadose zone hydrology (Flury and Wai, 2003, and references therein).

Detection of preferential flow in soils has also been achieved by applying a tracer to the soil surface and measuring its outflow concentration with time to produce a breakthrough curve. Bromide has been mainly used for this purpose (Everts and Kanwar, 1990; Lennartz et al., 1999; Haws et al., 2004; Brown et al., 2000; Jaynes et al., 2001) but also the dye rhodamine WT (Everts et al., 1989; Kung et al., 2000). Sorption or reactivity of bromide is reported to be negligible. In the case of pesticides, however, reactive transport is expected, and therefore conservative tracers might not realistically illustrate pesticide breakthrough to the groundwater. Furthermore, high bromide concentrations commonly used in tracer tests have been shown under certain conditions to inhibit pesticide degradation by reducing soil bacterial presence and activity and by altering pesticide sorption (Bech et al., 2017). Therefore, alternative tracers for illustrating pesticide breakthrough to groundwater are required.

The reactive nature of some fluorescent dye tracers has been exploited by using them as sorbing tracers as a surrogate to simulate pesticide leaching. At the laboratory scale, several studies have compared sorption and transport of atrazine and the dye rhodamine WT in column experiments (Sabatini and Austin, 1991; Everts and Kanwar, 1994; Kanwar et al., 1997). At the field scale, fluorescent dye tracers, such as uranine, sulforhodamine B, or rhodamine WT, have mainly been used for mimicking the transport of pesticides in wetlands (Passeport et al., 2010; Lange et al., 2011; Maillard et al., 2016). For evaluating pesticide transport by preferential flow in arable soils, dye tracers have been applied in tile-drainage plots (Czapar et al., 1994). These researchers compared the behavior of alachlor [2-chloro- $N$-(2,6-diethylphenyl)- $N$-(methoxymethyl) acetamide] and rhodamine WT during the first $10 \mathrm{~h}$ after application in field drainage tiles with silty clay loam soil. Even though both compounds differ in their chemical properties (molecular size, charge, octanol-water partition coefficient $\left[K_{\mathrm{OW}}\right]$, etc.), they found that rapid breakthrough of the herbicide correlated reasonably well with that of the dye, although different recovery rates were measured. Tile-drainage plots, however, show limitations in controlling total water, and therefore solutes, percolating through the soil profile (Bergström, 1990; Jacobsen and Kjær, 2007). Lysimeters offer a greater degree of control over environmental factors and solute mass balances can be properly established. Pesticide environmental behavior and fate in soils have been studied in numerous lysimeters studies (Bowman, 1990; Dousset et al., 1995; Vink et al., 1997; Francaviglia and Capri, 2000; Renaud et al., 2004; Kasteel et al., 2010; Schuhmann et al., 2016). Outdoor lysimeters are subject to climatic conditions similar to those of the surrounding field and provide information regarding the 
transport, plant uptake, and degradation of solutes under relevant soil water content regimes and crop production practices. To the best of our knowledge, comparison of pesticide and dye tracer transport through arable soils in large outdoor lysimeters has not been reported so far.

The main goal of this work was, therefore, to evaluate the suitability of different tracers as proxy for pesticide transport in arable soils by comparing their behavior with a model pesticide in outdoor lysimeters during a 2.5 -yr period. The herbicide atrazine was chosen as a model compound because its behavior in soil has been extensively studied. Uranine was used as a surrogate of atrazine leaching because similar sorption has been reported for uranine and atrazine (Sabatini and Austin, 1991). Furthermore, uranine is the most widely used fluorescent tracer in hydrological and hydrogeological applications. Thus, it is of considerable interest to know how it behaves relative to pesticides. Bromide, probably the most widely used tracer in soil sciences, was also included for comparison. Because we were mainly interested in the ability of tracers to track preferential transport, we performed the test in two soil types that were expected to show a different extent of preferential flow: a well-drained sandy-loamy Cambisol and a poorly drained loamy Cambisol. Conditions for preferential flow were promoted by applying heavy simulated rainfall shortly after atrazine application. Preferential flow was also artificially simulated by injecting the solutes below the root zone through a narrow tube.

\section{Materials and Methods}

\section{Compounds and Their Properties}

Atrazine is highly persistent in the environment and moderately mobile, with a low aqueous solubility $\left(30 \mathrm{mg} \mathrm{L}^{-1}\right.$ at $\left.20^{\circ} \mathrm{C}\right)$. It sorbs to clay minerals and organic matter (Mudhoo and Garg, 2011), showing a relatively low adsorption coefficient $\left(K_{\mathrm{OC}}\right)$, with values ranging from 40 to $394 \mathrm{~mL} \mathrm{~g}^{-1}$ (Burnett et al., 2000). Atrazine is degraded in the soil by both abiotic and biotic processes through hydrolysis and dealkylation (Mudhoo and Garg, 2011), with a half-life in aerobic soil ranging from 20 to $146 \mathrm{~d}$ (Burnett et al., 2000). Desethylatrazine (DEA) is the atrazine metabolite most frequently detected in groundwater (Kolpin et al., 2000; Loos et al., 2010). Desethylatrazine has a $K_{\mathrm{OC}}$ of $110 \mathrm{~mL} \mathrm{~g}^{-1}$ (Steinheimer and Scoggin, 2001), an aqueous solubility of $2700 \mathrm{mg} \mathrm{L}^{-1}$ at $20^{\circ} \mathrm{C}$, and a typical half-life in aerobic soil of $45 \mathrm{~d}$ (Lewis et al., 2016). It is classified as moderately persistent and moderately mobile (Lewis et al., 2016). The presence of DEA in concentrations greater than atrazine in groundwater has been documented in Europe (Loos et al., 2010).

In laboratory experiments with alluvial sandy aquifer material, Sabatini and Austin (1991) measured similar $K_{\mathrm{OC}}$ values of $120 \mathrm{~cm}^{3} \mathrm{~g}^{-1}$ for uranine and $148 \mathrm{~cm}^{3} \mathrm{~g}^{-1}$ for atrazine, even though both compounds differ in their chemical and physical properties: molecular weight ( 376 and $216 \mathrm{~g} \mathrm{~mol}^{-1}$ ), aqueous solubility (25,000 and $30 \mathrm{~m} \mathrm{~L}^{-1}$ ), acid dissociation constant $\mathrm{p} K_{\mathrm{a}}$ (5.1 and 1.68), and $\log K_{\mathrm{OW}}(-0.39$ and 2.34) for uranine and atrazine, respectively (Sabatini and Austin, 1991; Kasnavia et al., 1999; Lewis et al., 2016).

\section{Experimental Site}

This study was performed in a lysimeter facility from Agroscope at Zurich-Reckenholz, Switzerland $\left(47.26^{\circ} \mathrm{N}, 8.31^{\circ} \mathrm{E}, 443 \mathrm{~m}\right.$ asl). The facility consists of 12 weighing backfilled gravitation lysimeters (3.14- $\mathrm{m}^{2}$ surface area, $2.5-\mathrm{m}$ depth, $\sim 14,000 \mathrm{~kg}$ soil in each). The large outdoor lysimeters were constructed in 1979, and a sequence of arable crops has been grown since 1980 (Albisser and Prasuhn, 2013). Six of the lysimeters (L1-L6) were filled with a well-drained sandy-loamy Cambisol developed from a stony alluvium (gravel soil), and the other six (L7-L12) were filled with a poorly drained loamy Cambisol developed from moraine deposits (moraine soil) (Troxler et al., 1998). The two soil types are widely used for farming in Swiss lowlands and mainly differ in the texture of the $\mathrm{B}$ horizon and the draining properties of the parent material (Table 1). The moraine soil displayed lower water permeability and was slightly pseudogleyic (i.e., periodic water saturation of the soil leading to reducing conditions) (Troxler et al., 1998). Nievergelt (1997) calculated the available water capacity from the difference between the lysimeter weight at field capacity and the lowest lysimeter weight during a 16-yr study period and assessed it to be at least $260 \mathrm{~mm}$ for the moraine soil and $190 \mathrm{~mm}$ for the gravel soil. In the present study, all lysimeters were sown to corn (Zea mays L.) in 2014, to sugarbeet (Beta vulgaris ssp. vulgaris var. altissima Doel) in 2015, and to corn again in 2016 (Table 2). Only

Table 1. Main properties of the two soils

\begin{tabular}{|c|c|c|c|c|c|}
\hline \multirow[b]{2}{*}{ Soil horizon } & \multirow[b]{2}{*}{ Depth } & \multirow{2}{*}{$\begin{array}{l}\text { Organic } \\
\text { matter }\end{array}$} & \multicolumn{3}{|c|}{ Size distribution of mineral particles } \\
\hline & & & Clay & Silt & Sand \\
\hline & $\mathrm{cm}$ & & & $\%$ & 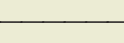 \\
\hline \multicolumn{6}{|c|}{$\underline{\text { Gravel soil }}$} \\
\hline$A_{p}$ & $0-50$ & 1.7 & 20 & 23 & 57 \\
\hline $\mathrm{B}_{1}$ & $50-60$ & 0.9 & 17 & 20 & 64 \\
\hline $\mathrm{B}_{2}$ & $60-70$ & 1.1 & 19 & 24 & 57 \\
\hline $\mathrm{B}_{3}$ & $70-100$ & & 20 & 24 & 57 \\
\hline $\mathrm{B}_{4}$ & $110-120$ & & 19 & 21 & 60 \\
\hline $\mathrm{C}$ & $120-135$ & & 17 & 18 & 65 \\
\hline $\mathrm{C}$ & \multicolumn{5}{|c|}{ sandy alluvial deposits } \\
\hline \multicolumn{6}{|c|}{$\underline{\text { Moraine soil }}$} \\
\hline$A_{p}$ & $0-50$ & 2.1 & 22 & 34 & 44 \\
\hline $\mathrm{B}_{1}$ & $50-70$ & 1.5 & 23 & 35 & 43 \\
\hline $\mathrm{B}_{2}$ & $70-90$ & 0.4 & 22 & 38 & 40 \\
\hline $\mathrm{B}_{3}$ & $90-110$ & & 20 & 40 & 40 \\
\hline $\mathrm{B}_{4}$ & $110-140$ & & 21 & 42 & 37 \\
\hline $\mathrm{C}$ & $140-160$ & & 20 & 41 & 38 \\
\hline $\mathrm{C}$ & \multicolumn{5}{|c|}{ loamy moraine deposits } \\
\hline
\end{tabular}


Table 2. Crops grown in the study period with sowing and harvest dates and winter cover

\begin{tabular}{|c|c|c|c|c|}
\hline Year & Crop & Sowing date & Harvest date & Winter cover \\
\hline 2014 & corn & 12 May 2014 & 10 Sept. 2014 & stubble \\
\hline 2015 & sugarbeet & 25 Mar. 2015 & 13 Nov. 2015 & bare fallow \\
\hline 2016 & corn & 12 May 2016 & 14 Sept. 2016 & stubble \\
\hline
\end{tabular}

eight out of the 12 lysimeters (L3-L10) were used in this study. The last four lysimeters (L1, L2, L11, and L12) were used for an additional experiment involving pesticide metabolites application (not included in this work). The lysimeter facility was covered with a plastic tunnel, and an irrigation system was used to ensure full control of irrigation rates.

\section{Irrigation}

Regular low-intensity irrigation events $(5-20 \mathrm{~mm}$ once a week at $0.2 \mathrm{~mm} \mathrm{~min}^{-1}$ ) were applied in addition to occasional intense irrigation events $\left(30-50 \mathrm{~mm}\right.$ at $\left.1 \mathrm{~mm} \mathrm{~min}^{-1}\right)$. The low-intensity irrigation events were performed using a fixed spray-irrigation system, whereas for the intense irrigation events, a mobile sprinkler system was used. Figure 1 shows daily and cumulative irrigation during the study period, and Table 3 details the heavy irrigation events. For enhancing atrazine leaching, high water content in the soil was maintained before application and an intense irrigation event was performed just after herbicide application.

During the study period (January 2014-December 2016), the total amount of water applied in each lysimeter by sprinkler irrigation was $\sim 2500 \mathrm{~mm}$. Approximately $950 \mathrm{~mm}$ was applied during 2014, $870 \mathrm{~mm}$ during 2015, and $690 \mathrm{~mm}$ during 2016. In a Federal Office of Meteorology and Climatology (MeteoSwiss) station located close to the lysimeter facility (Zurich-Affoltern, $47.43^{\circ} \mathrm{N}, 8.52^{\circ} \mathrm{E}, 444 \mathrm{~m}$ asl), the wettest months are from May to September. For the EbnatKappel station $\left(47.27^{\circ} \mathrm{N}, 9.11^{\circ} \mathrm{E}, 623 \mathrm{~m}\right.$ asl), irrigation data from
Table 3. Atrazine (and tracers) application to the lysimeters (L) and intense irrigation events during the study period

\begin{tabular}{|c|c|c|}
\hline Date & Atrazine (and tracers) application & $\begin{array}{l}\text { Intense } \\
\text { irrigation }\end{array}$ \\
\hline & & $\mathrm{mm}$ \\
\hline 14 May 2014 & - & 30 \\
\hline 30 May 2014 & $\begin{array}{l}\text { atrazine surface application (L4, L5, L8, L9): } \\
2.1 \mathrm{~kg} \mathrm{ha}^{-1}\end{array}$ & - \\
\hline 31 May 2014 & - & $40-55$ \\
\hline 3 June 2014 & - & $20-35$ \\
\hline 5 June 2014 & tracer application on surface (L4, L5, L8, L9) & $40-55$ \\
\hline 12 June 2014 & $\begin{array}{l}\text { atrazine depth injection (L3, L6, L7, L10): } 0.66 \mathrm{~g} \\
\text { per lysimeter; tracers were injected at the same } \\
\text { time }\end{array}$ & $40-55$ \\
\hline 28 July 2014 & - & 40 \\
\hline 31 July 2014 & - & $30-35$ \\
\hline 10 Sept. 2014 & - & 40 \\
\hline 15 Sept. 2014 & - & 40 \\
\hline 24 Feb. 2015 & - & 30 \\
\hline 6 May 2015 & - & 50 \\
\hline 21 May 2015 & - & 55 \\
\hline 3 Aug. 2015 & - & 30 \\
\hline 10 Aug. 2015 & - & 45 \\
\hline 7 Oct. 2015 & - & 40 \\
\hline 12 Oct. 2015 & - & 40 \\
\hline 28 June 2016 & - & 50 \\
\hline 4 July 2016 & - & 50 \\
\hline 31 Oct. 2016 & - & 50 \\
\hline 7 Nov. 2016 & - & 50 \\
\hline
\end{tabular}

2010 to 2014 shows that $>20 \mathrm{~mm}$ per 24 -h precipitation events are more frequent in December and between June and September. Onehour precipitation events of $>20 \mathrm{~mm}$ occur mainly in May and July. Accordingly, in these experiments, the heavy irrigation events were

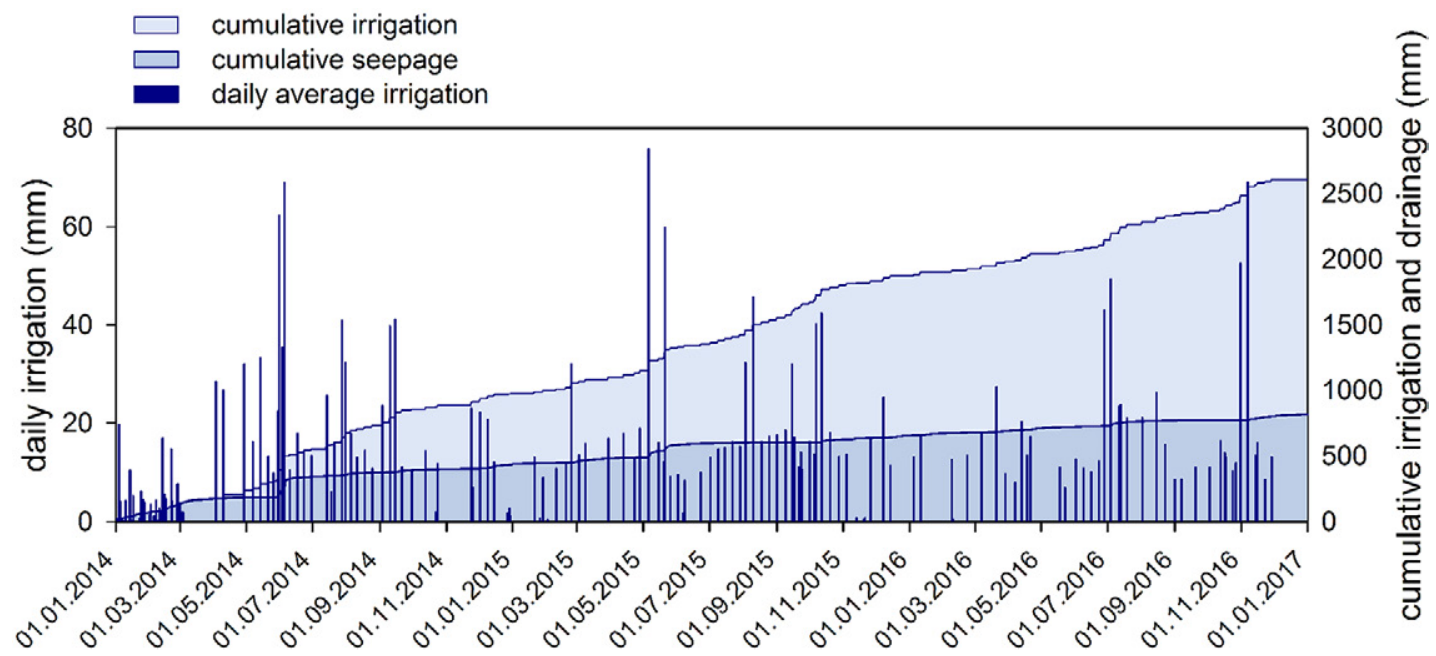

Fig. 1. Daily irrigation, cumulative irrigation, and cumulative drainage during the studied period for the gravel soil (Lysimeter L4). 
mostly performed in June through September and in November through December (Fig. 1).

\section{Pesticide and Tracer Application}

In four lysimeters (two replicates per soil type; L4, L5, L8, and L9), atrazine was applied at the surface as an early post-emergence herbicide at the two- to three-leaf stage, simulating the common scenario of herbicide application; whereas in the other four lysimeters (L3, L6, L7, and L10), atrazine was injected through a $40-\mathrm{cm}$ narrow tube below the root zone, simulating high preferential transport of the solutes through the topsoil.

For surface application, a sprinkler system was used, ensuring a uniform distribution of the pesticide on the soil surface of the lysimeter. On 30 May 2014, $22 \mathrm{~L}(7 \mathrm{~mm})$ of a $30 \mathrm{mg} \mathrm{L}^{-1}$ atrazine stock solution was applied at each lysimeter at $1 \mathrm{~mm} \mathrm{~min}^{-1}$, which corresponds to $659 \mathrm{mg}$ per lysimeter. This dose is equivalent to $2.1 \mathrm{~kg} \mathrm{ha}^{-1}$, just below the maximum recommended application rate of $2.2 \mathrm{~kg} \mathrm{ha}^{-1}$ (Syngenta, 2005). For depth injection, 11 injection points were uniformly distributed on the surface of each lysimeter. On 12 June 2014, $2 \mathrm{~L}$ of the atrazine stock solution were injected in each point at $1 \mathrm{~L} \mathrm{~min}^{-1}$ by using a 6 -mm-diameter metal rod with 1-mm-diameter holes around the bottom connected to a gear pump through a 3-mm i.d. Teflon tube. Thereafter, $1 \mathrm{~L}$ of water was poured in to rinse the injection apparatus. A similar pesticide injection procedure has been previously used for assessing the risk of groundwater contamination in relation to the depth of pesticide penetration (Delphin and Chapot, 2006). Given the surface area of each lysimeter, the injection rate corresponded to $0.46 \mathrm{~m} \mathrm{~d}^{-1}$, which is within the range of reported rates of preferential flow. Nimmo (2007) reviewed the infiltration velocity of preferential flow in 64 field test studies. The maximum flow rate in macropores for loamy sand, sandy soil, and silty clay loam ranged from 0.05 to $1.40 \mathrm{~m} \mathrm{~d}^{-1}$. Cey and Rudolph (2009) measured dye tracer infiltration rates for preferential flow in slightly stony silt loam ranging from 40.06 to $2.69 \mathrm{~m} \mathrm{~d}^{-1}$. Nevertheless, velocities up to $115 \mathrm{~m} \mathrm{~d}^{-1}$ for tracer transport along preferential pathways were measured by Jaynes et al. (2001) in fine-loamy soil. There was no atrazine application in 2015 and 2016 in any of the lysimeters.

In addition to atrazine, $\mathrm{NaBr}\left(500 \mathrm{~kg} \mathrm{ha}^{-1}\right)$ and uranine $\left(1.3 \mathrm{~kg} \mathrm{ha}^{-1}\right)$ were applied as tracers. Whereas the tracers were injected at the same time as atrazine in the lysimeters with depth injection, they were applied $6 \mathrm{~d}$ after atrazine in the lysimeters with surface application (5 June 2014) followed by a heavy irrigation event.

Previous tracer experiments $\left(500 \mathrm{~kg} \mathrm{NaBr} \mathrm{ha}^{-1}\right)$ were performed between October 2010 and April 2014 on the same lysimeters cropped with corn in 2010, potato (Solanum tuberosum L.) in 2011, broccoli (Brassica oleracea L. var. italica Plenck) in 2012, and a grass-clover mixture (standard mixture 330, Suter et al., 2012) in 2013 (Prasuhn et al., 2015). Low residual bromide content was detected in the soil and the drainage water before starting the present experiments. Decreased contents of bromide with depth were measured in the soil profile from 60 to $135 \mathrm{~cm}$ for the gravel soil (L4) and from 15 to $160 \mathrm{~cm}$ for the moraine soil (L9). The maximum measured content was $0.8 \mathrm{mg} \mathrm{kg}^{-1}$. The total bromide soil content corresponded to $<2 \%$ of the applied amount. Bromide concentration in the drainage water before the start of the experiments ranged from 0.1 to $0.5 \mathrm{mg} \mathrm{L}^{-1}$ for the gravel soil and between 0.3 and $0.9 \mathrm{mg} \mathrm{L}^{-1}$ for the moraine soil.

\section{Management Practices}

Crop management followed the good agricultural practices of the region. Because farm machinery cannot be used on lysimeters of this type, tillage practices were performed by hand to a depth of $20 \mathrm{~cm}$ before sowing the crops. After harvest, no tillage occurred until next spring.

Under corn, $\mathrm{N}$ fertilizer was applied as $\mathrm{NH}_{4} \mathrm{NO}_{3}$ and split into two applications ( 30 and $60 \mathrm{~kg} \mathrm{~N} \mathrm{ha}^{-1}$ ), whereas $\mathrm{P}$ and $\mathrm{K}$ were supplied before sowing ( $35 \mathrm{~kg} \mathrm{Pha}^{-1}$ as superphosphate and $183 \mathrm{~kg} \mathrm{~K} \mathrm{ha}^{-1}$ as potassium magnesia, respectively). Sugarbeet received applications of $110 \mathrm{~kg} \mathrm{Nha}^{-1}, 39 \mathrm{~kg} \mathrm{Pha}^{-1}$, and $309 \mathrm{~kg} \mathrm{~K} \mathrm{ha}^{-1}$, using the same fertilizers as for corn.

At harvest, the aboveground corn parts were cut off because the corn was grown for silage. Sugarbeet roots were removed from the lysimeters, whereas beet tops were left. Crop samples were taken for further analysis of bromide residues.

\section{Monitoring}

Pictures of the aboveground and belowground parts of the lysimeter facility can be found in Supplemental Fig. S1. Each lysimeter is set on a weigh bridge measuring the lysimeter weight at 5 -min intervals. The balances have an accuracy of $500 \mathrm{~g}(0.16-\mathrm{mm}$ water equivalent). The changes in the obtained values, which represent changes in the nominal mass, were divided by the lysimeter surface area and the density of water to obtain the changes in water content expressed as equivalent water column.

In two of the lysimeters (one for each type of soil), capacitive, multilevel probes EasyAG (Sentek) equipped with four frequency capacitance sensors (at 16, 36, 56, 76, and $96 \mathrm{~cm}$ for $\mathrm{L} 9$ and at 11 , 51 , and $71 \mathrm{~cm}$ for L4) were installed, and changes in volumetric soil water content were monitored at 15 -min intervals. A meteorological station was installed for measuring air temperature and relative humidity, wind speed and direction, and solar radiation. Data from all the sensors were collected with a DS3 datalogger (Sensorscope). All data were taken at 1-min intervals and were accessible in real time on the internet.

Drainage water was collected at the bottom of the lysimeters via stainless steel funnels and Teflon tubes in 54-L glass bottles placed on balances (PCE-SD 60 SST-C, PCE Instruments) to continuously record the outflow. The balances have a resolution of $20 \mathrm{~g}$ 
(0.066-mm water equivalent), and the data were monitored at 1-h intervals. Outflow data were divided by the lysimeter surface to obtain the cumulative drainage water expressed as equivalent water column. The leachate was subsampled for tracers and pesticide analysis every $50 \mathrm{~L}$. All leachate samples were stored at $4^{\circ} \mathrm{C}$ until analysis.

In May 2016, soil samples from the 0 - to 10 -cm depth were taken from the eight lysimeters for analysis of pesticide residues. Soil samples were stored at $4^{\circ} \mathrm{C}$ until analysis.

Evapotranspiration was estimated by the water balance computation during a specific period:

$$
\mathrm{ET}=I-D-\Delta \mathrm{SWS}
$$

where ET is evapotranspiration $(\mathrm{mm}), I$ is irrigation $(\mathrm{mm}), D$ is drainage $(\mathrm{mm})$, and $\Delta S W S$ is the change in soil water storage ( $\mathrm{mm})$ determined from lysimeter weight changes. Runoff can be excluded for the given lysimeters' construction. The 5-min-based time series of lysimeter weight changes was used for precisely determining daily irrigation and $\Delta S W S$ values. The processing of weight balance data consisted of five steps. In Step 1, the 5-min raw data were manually filtered, and all data during revision or control services were removed. In Step 2, a threshold filter was applied for removing outliers. In Step 3, if the resulting gaps did not exceed a period of $3 \mathrm{~h}$, values were estimated by linear interpolation. In Step 4 , an adaptive window and adaptive threshold filter (Peters et al., 2014; Hannes et al., 2015) was applied for correction of external forces such as management practices and wind. In Step 5, inconsistencies of the filter output were corrected manually on a daily basis.

\section{Chemicals and Reagents}

A $30 \mathrm{mg} \mathrm{L}^{-1}$ atrazine (Oskar Tropitzsch) solution was prepared in distilled water with $0.2 \%$ methanol. Sodium bromide and uranine (Fluorescein sodium salt, $\mathrm{C}_{20} \mathrm{H}_{10} \mathrm{O}_{5} \mathrm{Na}_{2}$ ) were purchased from VWR Chemicals and FluoTechnik, respectively.

Atrazine, desisopropylatrazine (DIA), and DEA (Pestanal quality), the single isotopically labeled surrogate (atrazine-D5, Pestanal quality), and the internal standard (terbuthylazine [6-chloro- $N$ (1,1-dimethylethyl)- $N^{\prime}$-ethyl-1,3,5-triazine-2,4-diamine], Pestanal quality) were purchased from Sigma Aldrich. Standard stock solutions $\left(1 \mathrm{mg} \mathrm{mL}^{-1}\right)$ were prepared in ethanol and stored in darkness at $-18^{\circ} \mathrm{C}$ for $6 \mathrm{mo}$. Working solutions $\left(10 \mu \mathrm{g} \mathrm{mL}^{-1}\right)$ were prepared by dilution of the stock solution in ethanol. These solutions were renewed every 2 mo. Atrazine, DIA, and DEA calibration solutions were prepared in a methanol/MilliQ $(70: 30 \mathrm{v} / \mathrm{v})$ mixture with concentrations ranging from 10 to $1000 \mu \mathrm{g} \mathrm{L}^{-1}$. Methanol, ethyl acetate, and ethanol of analytical grade were used. Ultrapure water was prepared by ultrafiltration with a Millipore DirectQ apparatus (Millipore).

\section{Extraction of Pesticides from Water Samples}

Leachate samples were filtered through $0.7-\mu \mathrm{m}$ glass fiber filters before extraction. For the pre-concentration and extraction of the pesticides, a combination of hydrophilic (Sepra ZT, Phenomenex) and hydrophobic (Bakerbond SDB-1, J.T. Baker) polymer-based sorbents with high specific surface area was used. Both sorbents show high adsorption capacity for highly polar micropollutants (Pichon et al., 1996; Mendaš, et al., 2001; Weigel et al., 2001; D’Archivio et al., 2007). Empty 6-mL solid-phase extraction (SPE) polyethylene cartridges (Grace) were packed with $0.2 \mathrm{~g}$ of each of the selected sorbents, with the Septra ZT as the first material in the enrichment flow direction and the SDB-1 as the second one, separated by polyethylene frits (Grace). The SPE cartridges were placed on a Phenomenex 12-position vacuum manifold. They were first rinsed with $3 \mathrm{~mL}$ of ethyl acetate, conditioned with $2 \times 3 \mathrm{~mL}$ of methanol, and finally washed with $2 \times 3 \mathrm{~mL}$ of MilliQ water. A 20 -mL sample was loaded on each cartridge using a $5 \mathrm{~mL} \mathrm{~min}^{-1}$ flow. Atrazine-d 5 was added to the samples at $1.25 \mu \mathrm{g} \mathrm{L}^{-1}$ for use as a surrogate standard. After the loading step, the sorbent was rinsed with $3 \mathrm{~mL}$ of MilliQ water and dried under vacuum for $15 \mathrm{~min}$. The target compounds were then eluted from the cartridges in 7.5-mL Pyrex glass tubes (VWR Scientific) with two portions of $1.5 \mathrm{~mL}$ of ethyl acetate at a flow rate of $3 \mathrm{~mL} \mathrm{~min}^{-1}$. The extracts were evaporated until dryness using a CentriVap benchtop vacuum concentrator (Labconco). The evaporated samples were reconstituted to obtain a volume of $500 \mathrm{~mL}$ of methanol/MilliQ (70:30 v/v) mixture. At this stage, the internal standard terbuthylazide was added at $50 \mu \mathrm{g} \mathrm{L}^{-1}$. The SPE recoveries at concentrations between 0.5 and $25 \mu \mathrm{g} \mathrm{L}^{-1}$ ranged from 84 to $100 \%$ for atrazine and from 97 to $113 \%$ for DEA.

\section{Analytical Methods}

The bromide concentration in the drainage water was measured by ion chromatography using a Dionex LC20 chromatograph with ED40 electrochemical detector (Dionex Corp.). The detection limit was $0.014 \mathrm{mg} \mathrm{L}^{-1}$. Bromide in the crop samples was extracted with water. An additive of trichloroacetic acid was used for precipitation of proteins. Bromide concentrations were then measured as explained above.

Uranine concentrations were measured by fluorescence spectrometry using a PerkinElmer LS-50B luminescence spectrometer. The excitation wavelength was set to $488 \mathrm{~nm}$, and emission was measured at $516 \mathrm{~nm}$, with excitation and emission slits of $28 \mathrm{~nm}$. To transform relative fluorescence units into uranine concentrations, a six-point standard curve was established using increasing concentrations of uranine from 0.1 to $5 \mu \mathrm{g} \mathrm{L}^{-1}$. The quantification limit was $0.05 \mu \mathrm{g} \mathrm{L}^{-1}$.

Atrazine, DIA, and DEA concentrations in the SPE eluates were determined by ultra-high-pressure liquid chromatography quadrupole time-of-flight mass spectrometry. A Synapt G2 Q-TOF mass spectrometer (Waters) equipped with an electrospray probe was used. Quantification of atrazine, DIA, and DEA was performed 
by the internal standard method based on peak areas using terbuthylazine as the internal standard. The estimated instrument method quantification limit was $3,11.4$, and $6 \mu \mathrm{g} \mathrm{L}-1$ for atrazine, DIA, and DEA, respectively. The corresponding method quantification limits, corrected for the SPE concentration factor, were $0.075,0.28$, and $0.15 \mu \mathrm{g} \mathrm{L}-1$, respectively.

There was no difference in detection sensitivity to the mass applied between bromide and the other two solutes. The quantification limit for atrazine was 187 times lower than for bromide, and 185 times more bromide mass was applied. In the case of uranine, the quantification limit was 280 times lower than for bromide, and 299 times more bromide mass was applied. Therefore, breakthrough results for the three solutes can be compared without applying any correction.

Soils samples were sent to an external, DIN-certified laboratory (Eurofins Sofia $\mathrm{GmbH}$ ) for pesticide extraction and analysis by liquid chromatography coupled with tandem mass spectrometry. The quantification limit was $0.05 \mathrm{mg} \mathrm{kg}^{-1}$.

\section{Results and Discussion}

\section{Water Dynamics}

Daily irrigation and soil water content variations at two different depths for the moraine (L9) and gravel soil (L4) are shown in
Fig. 2 and 3, respectively. In the moraine soil (L9), rapid soil water content increases were observed at the 16-cm depth after any irrigation event, whereas at the 56 -cm depth, only intense irrigation events led to rapid and significant soil water content rises (Fig. 2). For example, following 20- and 13-mm irrigation events on $28 \mathrm{Apr}$. and 15 May 2015, respectively, rapid (within $3 \mathrm{~h}$ ) soil water content increases occurred at the $16-\mathrm{cm}$ depth but not at the $56-\mathrm{cm}$ depth. Following the 6 May 2015 intense irrigation event $(54 \mathrm{~mm})$, however, a significant increase in soil water content was recorded at both the 16 (within $1 \mathrm{~h}$ ) and 56-cm depths, although the latter was not recorded until $3 \mathrm{~h}$ later. Fluctuations in the soil water content were smaller for the gravel soil (L4; Fig. 3), especially at greater depths. Because the occurrence of sidewall flow (i.e., potential artificial water and solute flow along the inside of the lysimeter wall) can be disregarded because of the dimensions of the present lysimeters (Bergström, 2000; Fank, 2009), this rapid rise of deep soil water content could only be related to preferential paths of water flow as a result of the presence of macropores or because of spatial variability in soil properties. The presence of conductive zones through which matrix flow may have been unexpectedly fast could have delivered water to greater depths. Nevertheless, preferential flow through macropores, which are likely to occur in the moraine but not in the gravel soil, seems to be the most likely explanation of the results. Breakthrough of the applied solutes will allow further discussion of this hypothesis.

Daily irrigation, cumulative irrigation, and cumulative drainage for one of the lysimeters are shown in Fig. 1. Drainage volumes

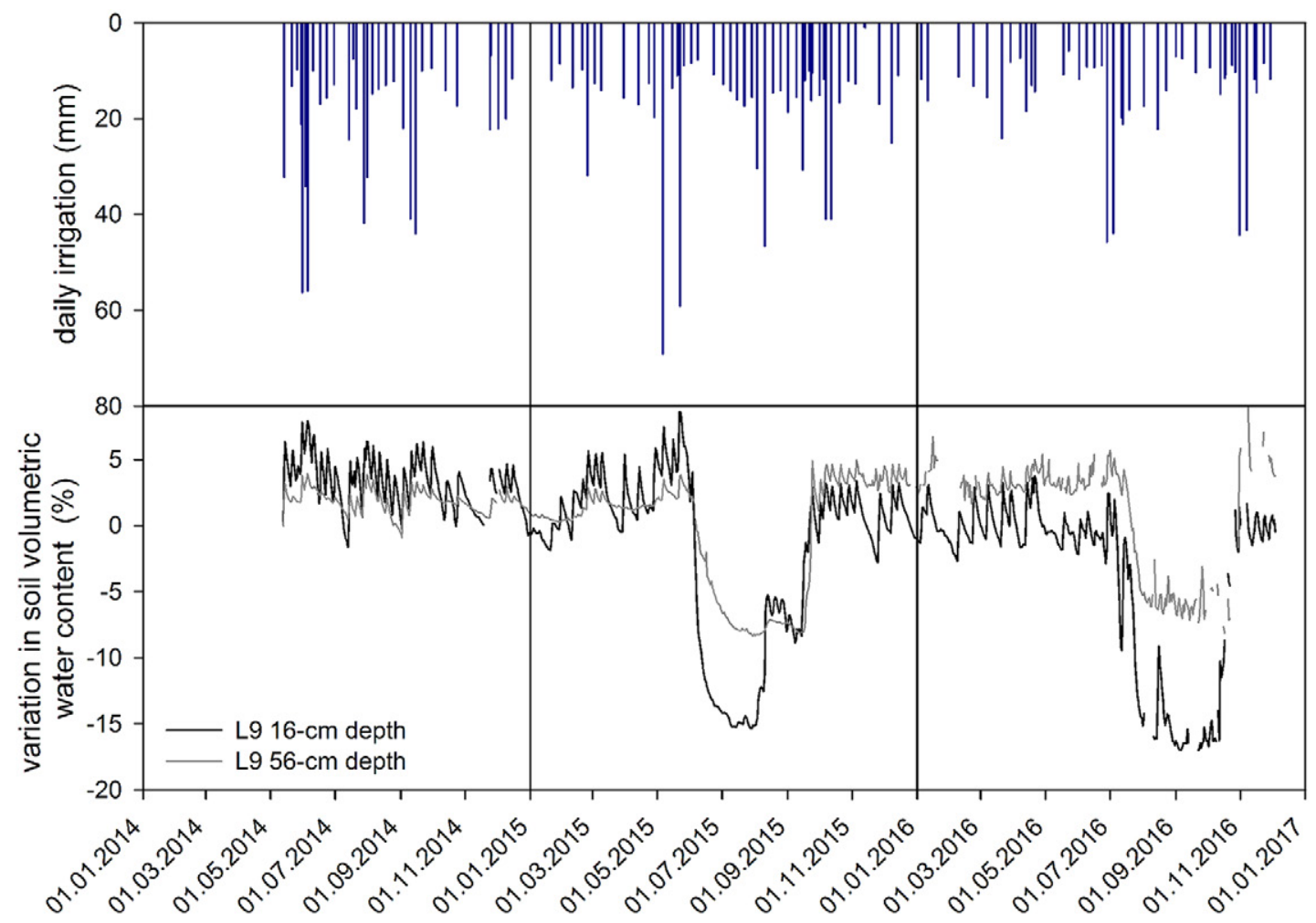

Fig. 2. Daily irrigation and variations in soil water content (with respect to the soil water content on 13 May 2014) at two different depths during the studied period for the moraine soil (Lysimeter L9). 


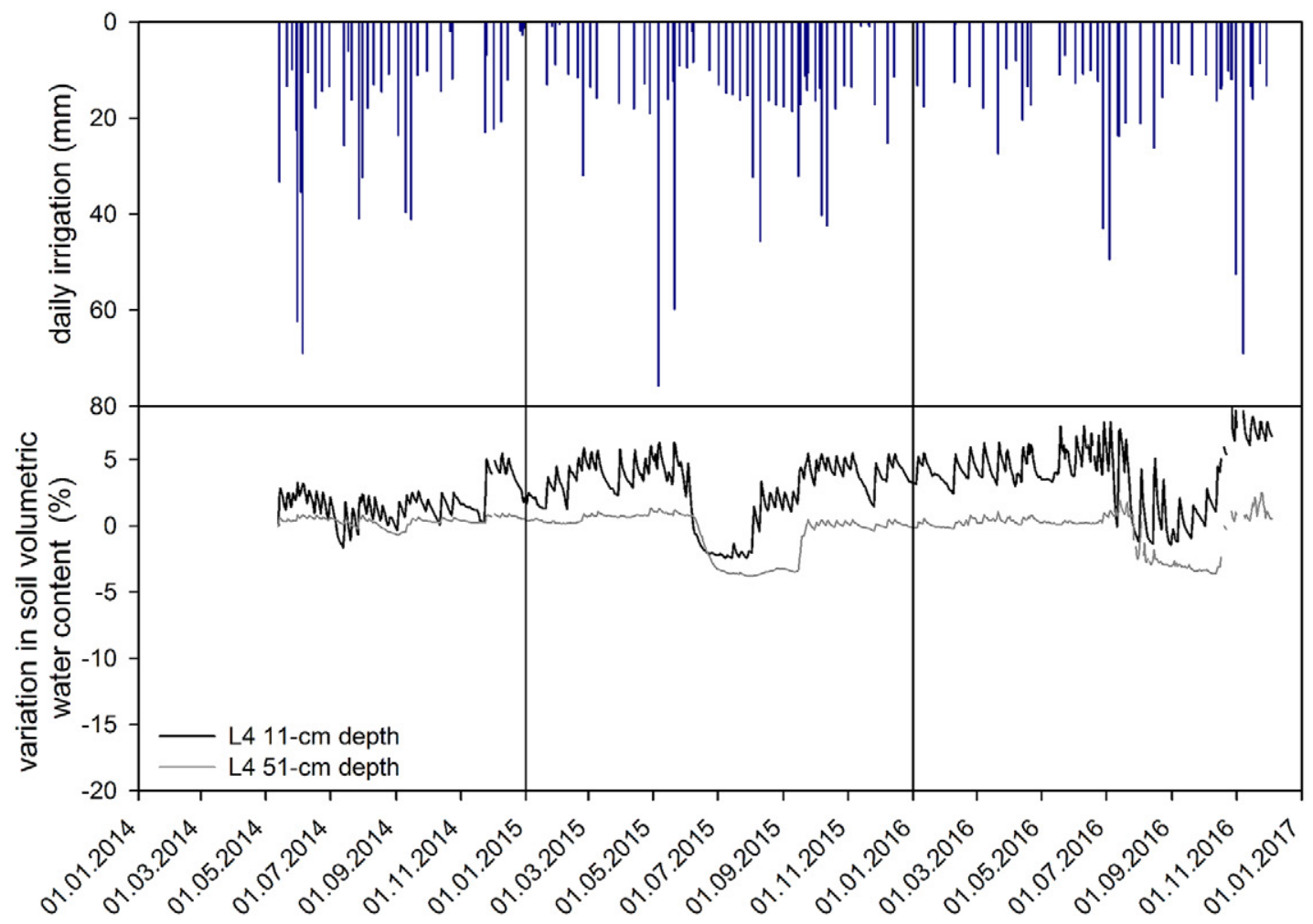

Fig. 3. Daily irrigation and variations in soil water content (with respect to the soil water content on 13 May 2014) at two different depths during the studied period for the gravel soil (Lysimeter L4).

during the study period were between 700 and $900 \mathrm{~mm}$. In relation to water input, drainage volume represented $45 \%$ of the total irrigation in 2014, $25 \%$ in 2015, and 20\% in 2016. Increased drainage coincided with periods of high irrigation volume and high soil water content. The two most significant increases in the drainage rate occurred after the intense irrigation following solute application (31 May 2014) and after the intense irrigations on 6 and 22 May 2015. For both soil types, these two intense irrigation events promoted a rapid and significant response in the drainage at the bottom of the lysimeter, as shown for L4 in Fig. 1. Monthly, the highest drainage volumes were obtained in May through June and in December through March (Fig. 4). Similar drainage volumes were observed for the two soil types, although in 6 of $36 \mathrm{mo}$, drainage amounts were $5 \mathrm{~mm} \mathrm{mo}^{-1}$ higher in the gravel than the moraine soil (Fig. 4; Supplemental Table S1).

A water balance approach was adopted to compute the estimated monthly ET for each lysimeter and year following Eq. [1]. The accumulated values of $I, D$, and ET for one of the lysimeters are illustrated in Supplemental Fig. S2. The average monthly and total sums of all components are shown in Fig. 4 and listed in Supplemental Table S1 as the average across the four lysimeters for each soil type. The ET for all the lysimeters averaged $541 \mathrm{~mm} \mathrm{yr}^{-1}$ in 2014, $664 \mathrm{~mm} \mathrm{yr}^{-1}$ in 2015, and 598 $\mathrm{mm} \mathrm{yr}^{-1}$ in 2016. Evapotranspiration was similar in the gravel (544-642 $\mathrm{mm} \mathrm{yr}^{-1}$ ) and moraine soils (537-683 $\mathrm{mm} \mathrm{yr}^{-1}$ ). On a monthly basis, the ET was higher from May to September (Fig.
4) when average air temperature and plant growth were high (Supplemental Fig. S3).

\section{Bromide, Uranine, and Atrazine Breakthrough after Surface Application}

With surface application, in the moraine soil, the maximum concentration of bromide ( $82 \mathrm{mg} \mathrm{L}^{-1}$ for L9 and $115 \mathrm{mg} \mathrm{L}^{-1}$ for L8) occurred within $360 \mathrm{~d}$, after $\sim 400$ to $450 \mathrm{~mm}$ of cumulative drainage, followed by a steady decrease (Fig. 5). Table 4 summarizes the observed tracers and atrazine breakthrough parameters for each lysimeter. In the gravel soil, a similar pattern was observed, although high bromide peaks (maximum concentration of 184 and $124 \mathrm{mg} \mathrm{L}^{-1}$ for $\mathrm{L} 4$ and L5, respectively) were more rapidly reached after 290 to $330 \mathrm{~d}$ and 300 to $350 \mathrm{~mm}$ of cumulative drainage, respectively (Fig. 5; Table 4). This is consistent with the higher water retention capacity of the moraine soil than the gravel soil.

The leaching patterns of uranine and atrazine were different from that of bromide (Fig. 5). Under the moraine soil, both solutes were detected in the first leachate collected after the intense irrigation that followed application — within a few hours—and the maximum concentration occurred after only $100 \mathrm{~mm}$ of accumulated drainage (Table 4). Thereafter, the uranine concentration decreased to below the detection limit between 50 and $100 \mathrm{~d}$ after application, after which it was not detected anymore. In the case of atrazine, after the initial peak, continuous low concentrations in the drainage water (below $4 \mu \mathrm{g} \mathrm{L}^{-1}$ ) were observed during several months (until 280 

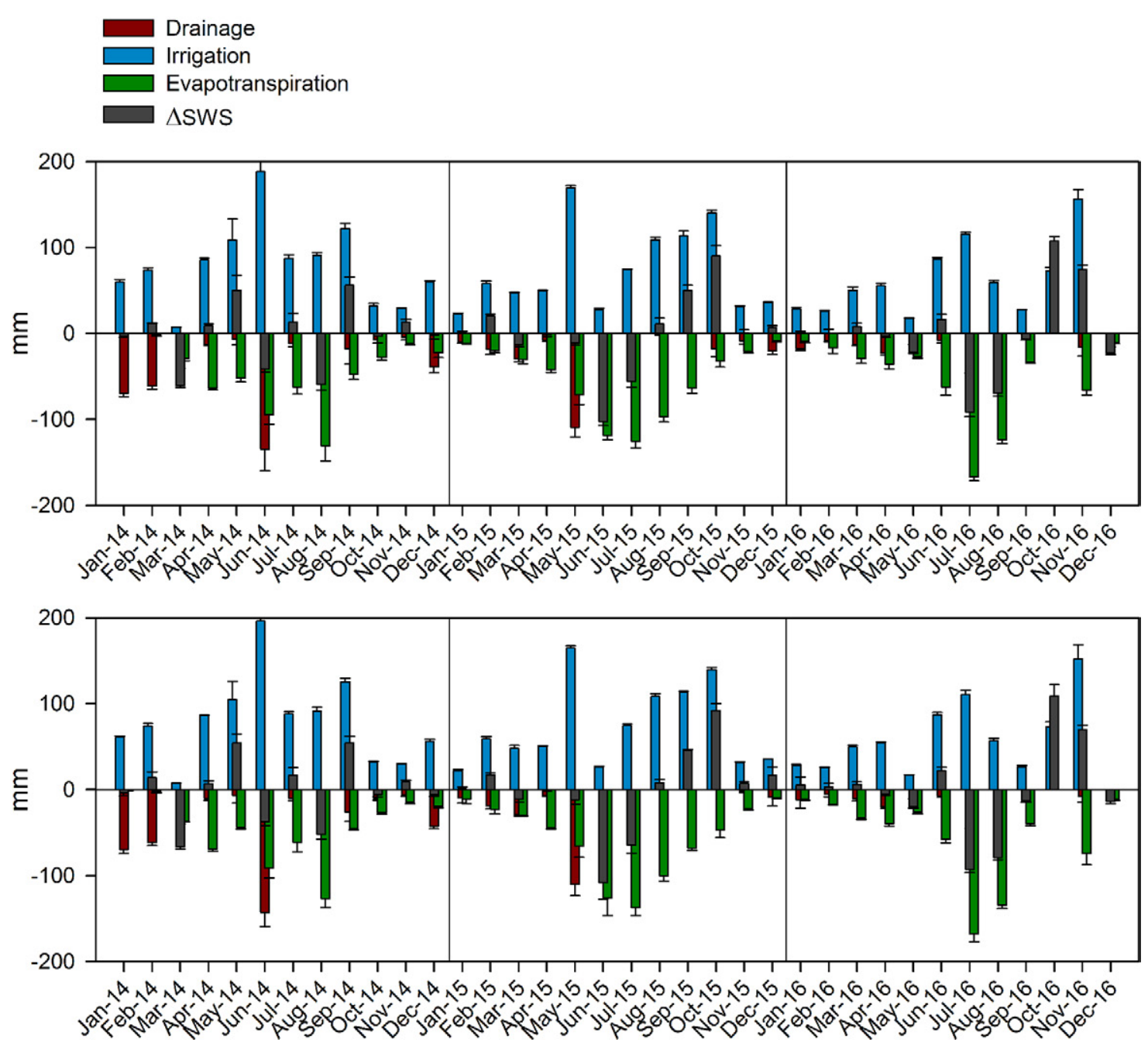

Fig. 4. Average monthly irrigation, drainage, evapotranspiration, and the change in water storage ( $\Delta S W S$ ) for the gravel (upper panel) and moraine soils (lower panel) during the three monitoring years.

$\mathrm{d}$ after application). In the gravel soil, neither uranine nor atrazine rapid breakthrough was observed. Concentrations of both solutes remained below the detection limit during the first 200 to $300 \mathrm{~d}$.

The heavy irrigation on 24 Feb. 2015 (Fig. 1; Table 3) caused a small atrazine breakthrough peak $\sim 280 \mathrm{~d}$ after application in both soil types, more significant for the moraine than the gravel soil. For the moraine soil, the occurrence of this peak coincided with a sharp increase in the bromide concentration. The heavy irrigation events on 6 and 22 May 2015 (340 and 356 d after application, respectively) caused a significant increase in the drainage volume and promoted greater atrazine leaching. As a result, another atrazine pulse occurred $340 \mathrm{~d}$ after application in both soil types (the first peak in the case of the gravel soil) once the cumulative drainage volume was higher than 300 to $350 \mathrm{~mm}$ (Fig. 5). This peak lasted for 1 to $2 \mathrm{mo}$ (cumulative drainage to $\sim 400-500 \mathrm{~mm}$ ) followed by a long period with small and slow arrivals coincident with a very low drainage rate and soil water content. For the moraine soil, this atrazine peak occurred at the same time as the maximum concentration of bromide was reached, whereas for the gravel soil there was a delay of $7 \mathrm{~d}$.
Atrazine degradation was confirmed by the detection of metabolites (mostly DEA). For the moraine soil, low DEA contents $(<0.2$ $\left.\mu \mathrm{g} \mathrm{L}{ }^{-1}\right)$ were measured during the initial atrazine breakthrough followed by a period with a gradual increase of DEA concentration with time, although some fluctuations occurred (Fig. 6). A significant increase in the concentration of DEA in the drainage water was observed after $340 \mathrm{~d}$, coinciding with the atrazine peak of May 2015. A similar DEA pattern was observed for the gravel soil, even though atrazine contents remained close to the detection limit during the first $250 \mathrm{~d}$. Desethylatrazine is considered less persistent (lower half-life) and more mobile (higher solubility) than atrazine, showing a high leaching potential to groundwater. Accordingly, significant leaching of DEA to the drainage water was observed.

\section{Bromide, Uranine, and Atrazine Breakthrough after Depth Injection}

In the experiments with depth injection, similar bromide breakthrough curves as those for surface application were observed except that measured concentrations were higher and the peaks 


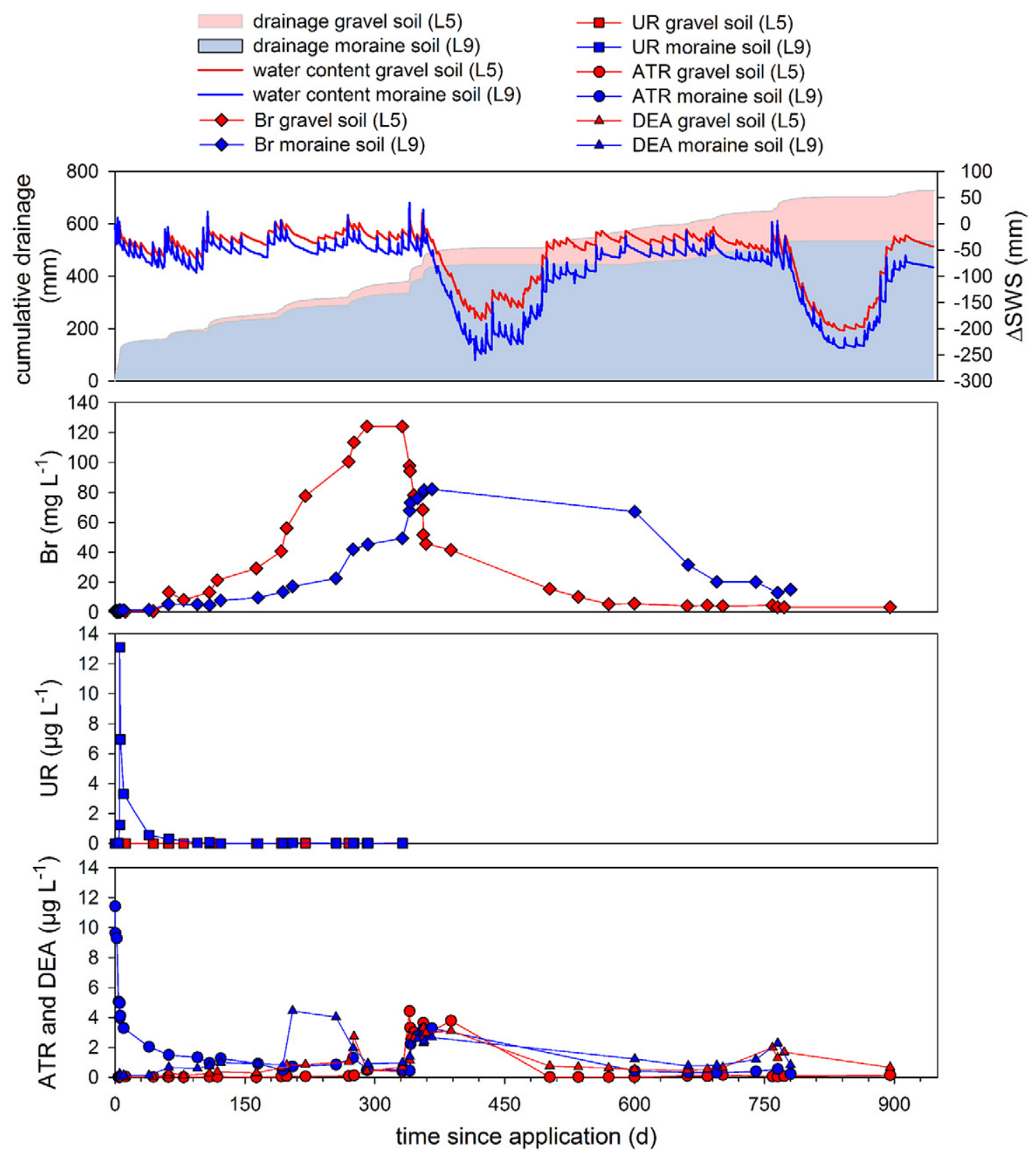

Fig. 5. Bromide (Br), uranine (UR), atrazine (ATR), and desethylatrazine (DEA) breakthrough curves after surface application in the gravel (Lysimeter L5) and moraine soils (Lysimeter L9). Cumulative drainage and changes in the soil water storage ( $\triangle$ SWS) for each lysimeter are also shown.

were reached earlier after only 180 to $220 \mathrm{~mm}$ of accumulated drainage (Fig. 6). Interestingly, maximum bromide concentrations were achieved at the same time in both soils, in contrast to observations for surface application (Table 4).

For the moraine soil, both uranine and atrazine early breakthrough peaks were reached after a small amount of accumulated drainage ( $<55 \mathrm{~mm}$ for both L6 and L7; Table 4), in line with observations for surface application. Maximum concentrations were higher and were achieved faster than with surface application in $<24 \mathrm{~h}$ (up to $40 \mu \mathrm{g} \mathrm{L}^{-1}$ uranine and up to $110 \mu \mathrm{g} \mathrm{L}^{-1}$ atrazine; Fig. 6). For the gravel soil (L3 and L6), uranine and atrazine were also detected in the first leachates collected after injection, in contrast to observations for surface application. A peak of up to $22 \mu \mathrm{g} \mathrm{L}^{-1}$ uranine was achieved within $3 \mathrm{~d}$ (L6, much lower for L3), whereas the atrazine peak (up to $46 \mu \mathrm{g} \mathrm{L}^{-1}$ ) was reached in 10 to $50 \mathrm{~d}$ (Table 4).

As in surface application, another atrazine peak was observed 330 to $340 \mathrm{~d}$ after injection ( $\sim 210-250 \mathrm{~mm}$ of accumulated drainage) in both soil types subsequent to intense irrigation (Fig. 6). Measured atrazine peak concentrations were higher than with surface application and higher for the gravel than the moraine soil. Interestingly, for both soil types, before the occurrence of this May 2015 peak, additional atrazine pulses were observed after intense irrigation events. The response to heavy irrigation was therefore 


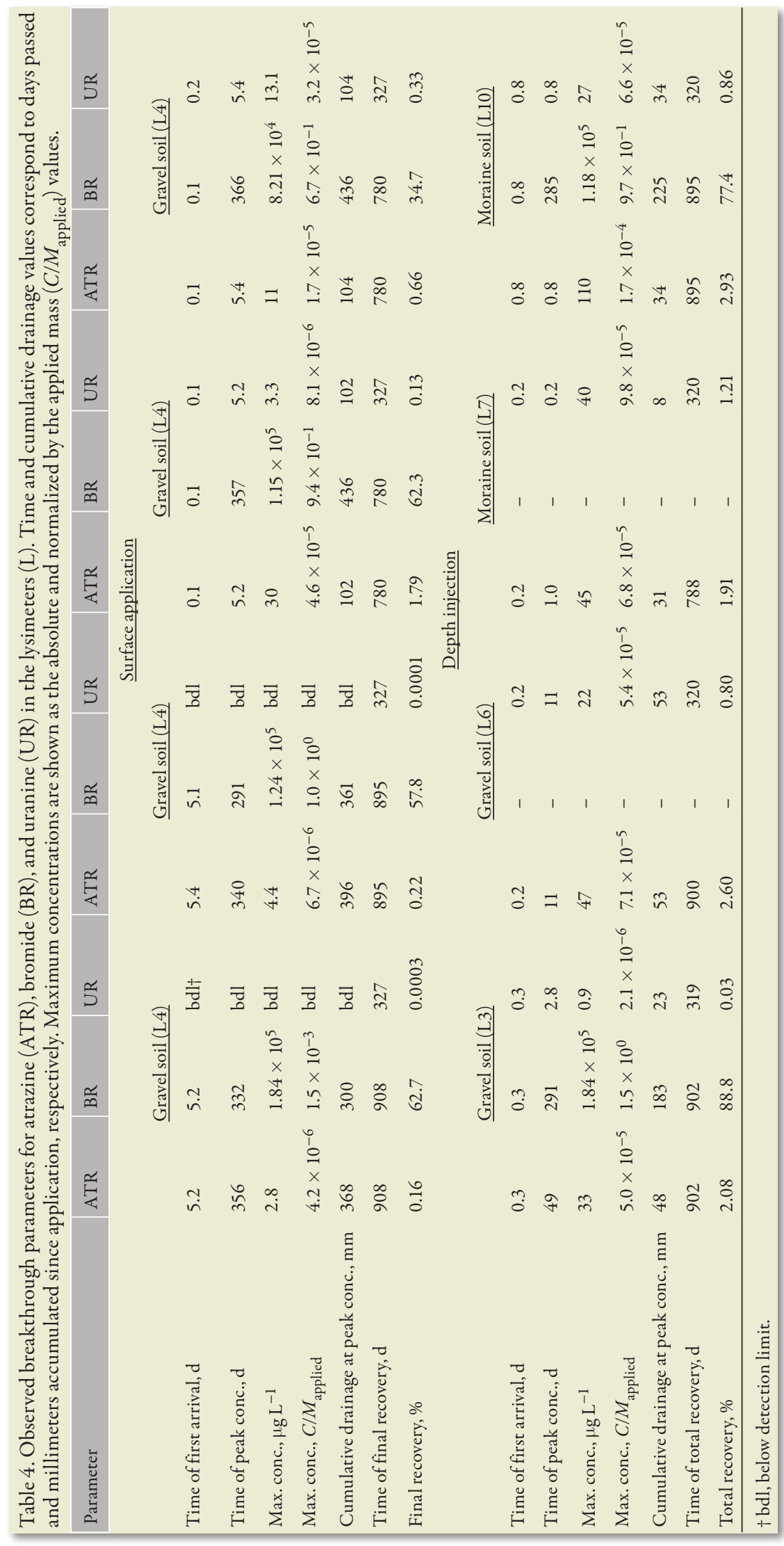

more significant than with surface application. During and right after application, a higher mass of atrazine was probably transported deeper in the lysimeters with depth than in the lysimeter with surface application, and therefore the increases in water and solute mass flux after these intense irrigation events triggered atrazine leaching. These additional pulses were more intense in the gravel than the moraine soil. Peak concentrations were considerably lower in these additional pulses than the initial breakthrough probably because of degradation and longer contact times, allowing the herbicides to diffuse into the less-mobile pore water. As in the surface application, slight pesticide breakthrough took place during the period with a very low drainage rate and soil water content (Fig. 6).

As observed with surface application, a continuous breakthrough of DEA was detected except for the first days after injection (Fig. 6). Some fluctuations in the DEA concentration were observed, coinciding with the atrazine peaks. The DEA concentrations were, in general, higher for the moraine than the gravel soil. Although biological activity and organic matter content decrease with depth (Table 1), the detection of DEA in the drainage water of the lysimeters in which atrazine was injected at $40 \mathrm{~cm}$ suggests that atrazine degradation occurred even at depths greater than $40 \mathrm{~cm}$, albeit probably to a lesser extent than in surface application.

Therefore, atrazine (and DEA) leaching was driven by large drainage events for both application methods. Several intense irrigation events were performed during the monitoring period (Fig. 1; Table 3), which led to increases in the drainage volume consistent with the change in the soil water content. The event following atrazine application (May-June 2014) and the one performed in May 2015 (340 d after application) resulted in the two main atrazine leaching events (Fig. 5 and 6). Between 30 May and 5 June 2014 for lysimeters with surface application and between 30 May and 13 June 2014 for lysimeters with depth injection, $\sim 175 \mathrm{~mm}$ of irrigation was applied. Between 6 and 21 May 2015, $160 \mathrm{~mm}$ was irrigated. These amounts are significantly higher than the water applied during other heavy irrigation events (Fig. 1; Table 3). These findings 


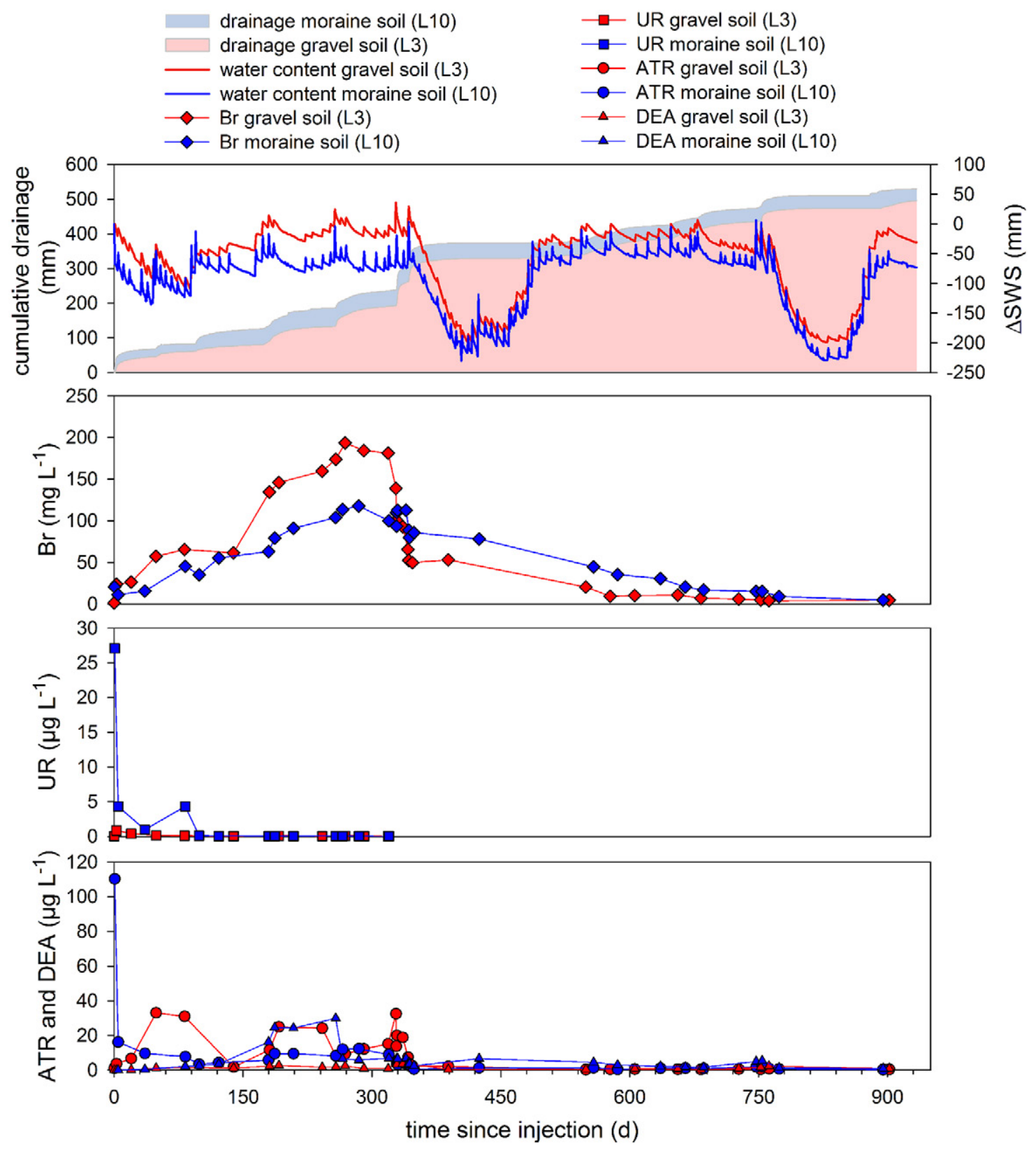

Fig. 6. Bromide (Br), uranine (UR), atrazine (ATR), and desethylatrazine (DEA) breakthrough curves after depth injection in the gravel (Lysimeter L3) and moraine soils (Lysimeter L10). Cumulative drainage and changes in the soil water storage ( $\Delta S W S$ ) for each lysimeter are also shown.

are consistent with previous studies that have shown that pesticide preferential flow increases with irrigation intensity (Edwards et al., 1992; McGrath et al., 2010). Nevertheless, the occurrence of macropore flow seems to depend also on the soil water content. Some studies have found that wetter soils tend to generate more macropore flow than drier soils as a result of reduced lateral losses into the soil matrix (Beven and Germann, 1982; Greve et al., 2010; Jarvis, 2007) and that higher antecedent soil water content increases the depth to which macropore flow penetrates (Greve et al., 2010). Other field studies have shown, however, that antecedent wetness does not necessarily govern preferential flow occurrence (Flury et al., 1994; Hardie et al., 2011). This is also consistent with the nonequilibrium flow theory (Jarvis, 2007), which indirectly implies that water flow through macropores occurs independently of antecedent wetness conditions (Beven and Germann, 2013). In the present experiments, the relationship between soil water content before irrigation and the occurrence of preferential flow was not straightforward (Supplemental Fig. S4). It seems that the occurrence of preferential flow is mainly governed by the intensity of the irrigation. The effect of the previous soil water content cannot be evaluated because, for the two heavy irrigation events that promoted significant preferential flow, antecedent wetness conditions were similar.

\section{Solute Mass Balances}

At the end of the monitoring period ( $900 \mathrm{~d}$ after application), an average of $0.7 \%$ of the surface-applied atrazine mass was recovered 
in the drainage water $(0.2 \%$ for the gravel and $1.2 \%$ for the moraine soil), similar to what was observed for uranine (up to $0.3 \%$ ) (Table 4). Similar low recoveries of atrazine in drainage water (0.01-0.5\%) have been previously reported in subsurface-drained fields and in lysimeters (Hall et al., 1991; Kladivko et al., 1991; Masse et al., 1996; Dousset et al., 2004; Fortin et al., 2002). Higher recoveries were obtained with depth injection: $2.3 \%$ for the gravel and $2.4 \%$ for the moraine soil, which are on the same order of magnitude than the uranine recovery (up to 1.2\%) (Table 4). In both soil types, recovery of DEA in the drainage water $900 \mathrm{~d}$ after atrazine application corresponded to only 0.4 and $1.8 \%$ of the atrazine applied mass for surface and depth application, respectively.

Pesticide residues in the crops were not measured, but Roeth and Lavy (1971) reported 12 to $23 \%$ uptake of ${ }^{14} \mathrm{C}$-atrazine by corn after 4 wk of growth in sandy-loamy soil in laboratory experiments. Furthermore, no residues of atrazine were detected in the 0 - to 10 -cm soil layer 2 yr after application.

Assuming similar atrazine uptake by the crop as that found by Roeth and Lavy (1971), in the present experiments at least $73 \%$ of the applied atrazine was therefore degraded or sorbed to the soil particles. Based only on the concentration of atrazine and DEA, quantification of atrazine (and DEA) degradation is not possible

surface application, gravel soil (L5)

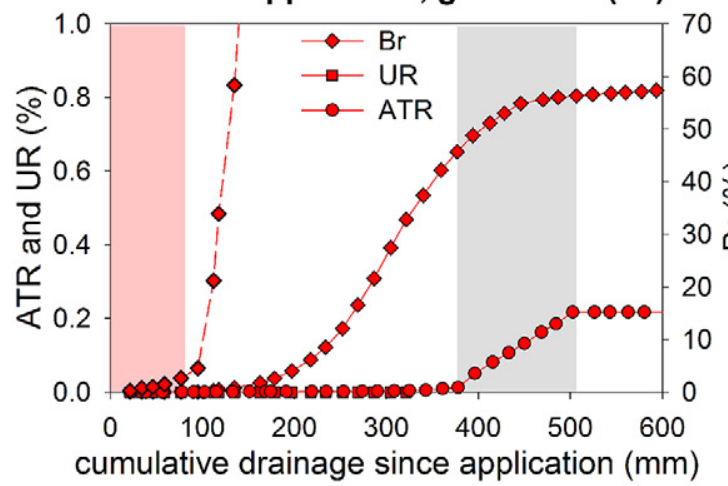

because of several issues such as further transformation of DEA, production of other metabolites in addition to DEA (e.g., DIA and atrazine-2-hydroxy), selective sorption, or new recharge of atrazine into the system. Here, compound-specific isotope analysis may serve as a complementary tool to identify and quantify pesticide degradation (Fenner et al., 2013; Meyer and Elsner, 2013).

The present experiments were performed using free-drainage lysimeters, where water is allowed to drain freely through the soil under gravity. The lower boundary of the lysimeter is exposed to atmospheric pressure, and therefore, because of the disruption of the hydraulic gradient, a water-saturated zone must form at the bottom of the lysimeter before water can drain. In general, such a local saturation does not occur in the field. However, in the case of soils with tube drainage, free-draining lysimeters might be an accurate representation of field conditions. Modeling and experimental studies comparing solute transport in free-drainage lysimeters and under field conditions have reported differences in relation to soil texture, water fluxes, pore-water velocity, soil heterogeneity, sorption, and solute leaching (Flury et al., 1999; Abdou and Flury, 2004; Kasteel et al., 2007, 2010; Boesten, 2007). Therefore, the results of the present experiments need to be used with caution when transferring to field conditions, especially in the case of the moraine soil, where significant preferential flow occurred and
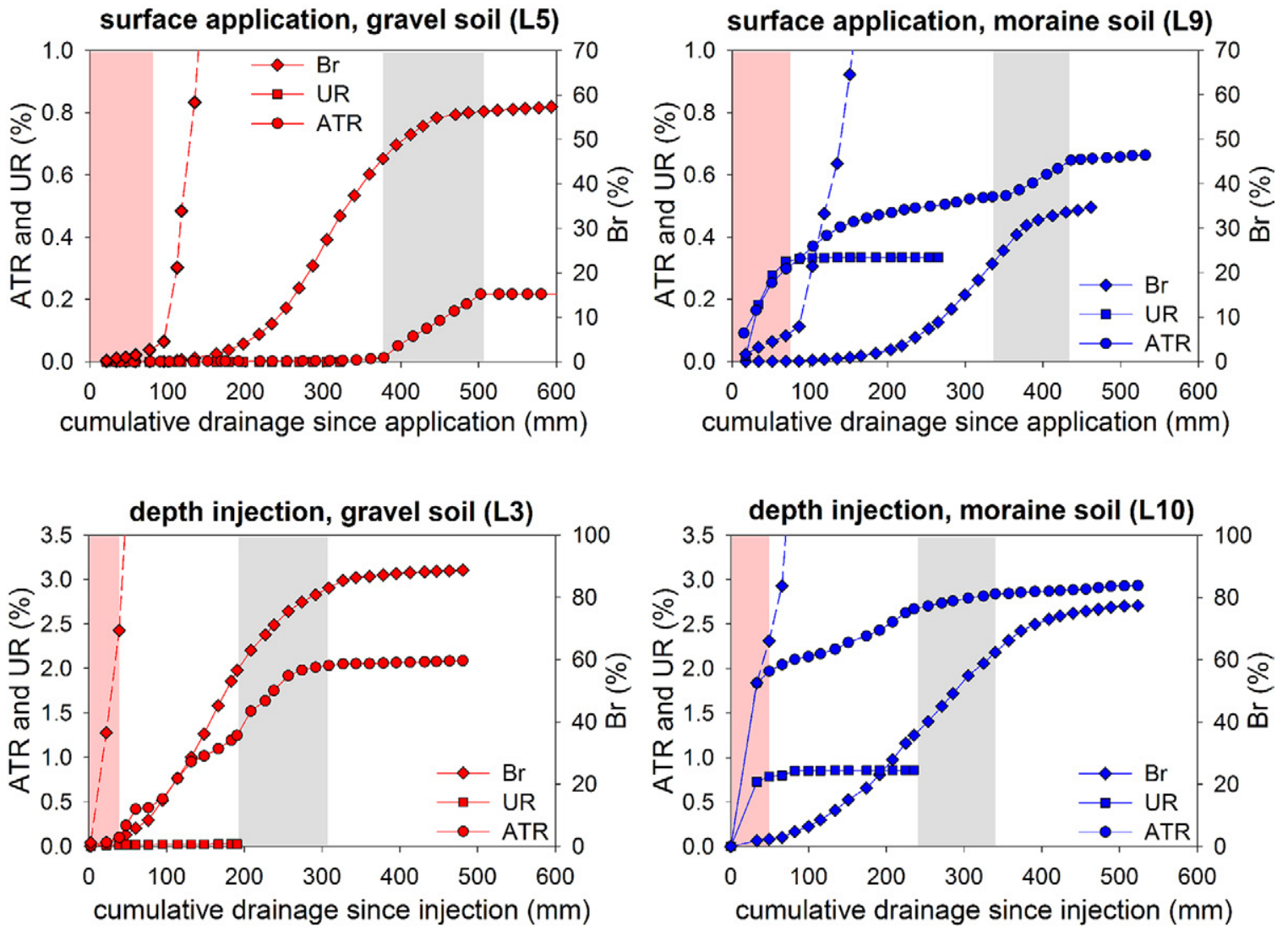

Fig. 7. Atrazine (ATR), bromide (Br), and uranine (UR) breakthrough curves against cumulative drainage for the four combinations of application method and soil type. Note that the scale for bromide recovery (solid lines) is different than for the other two solutes. For comparison during the first $150 \mathrm{~mm}$, bromide curves are also shown using the same scale as for atrazine and uranine (dashed lines). The shaded areas show the two main irrigation and drainage events. 
therefore the amount of atrazine leached might be underestimated (Vereecken and Dust, 1998; Abdou and Flury, 2004).

Total bromide recovery was between 35 and $63 \%$ of the applied mass for surface application and between 77 and $89 \%$ for depth injection (Table 4). Higher recoveries were achieved in the gravel than the moraine soil. Therefore, total recoveries of bromide $900 \mathrm{~d}$ after application were $\sim 40$ and 100 times higher than for atrazine and uranine, respectively. The removal of bromide by harvested plant products was low. With surface application, 10 to $13 \%$ of the applied bromide was found in corn plants harvested 3 mo after application, and between 0.1 and $1 \%$ was removed by sugarbeet harvested $17 \mathrm{mo}$ after application. As expected, because of the deeper injection, the removal of bromide by plant uptake and harvesting was lower with depth injection than with surface application (5-7\% for corn and $0.1-0.3 \%$ for sugarbeet). Similarly, in a previous experiment on the same lysimeters, 3.5 to $3.9 \%$ of the applied bromide was found in corn harvested 3 mo after application (Prasuhn et al., 2015). On other lysimeters at the same site, Prasuhn et al. (2015) measured 3.0 to $4.2 \%$ of the applied bromide in sugarbeet harvested 5 mo after application.

\section{Comparison of the Behavior of Pesticides and Adsorbing and Nonadsorbing Tracers}

For evaluating the use of adsorbing fluorescent dye tracers (uranine) and conservative nonadsorbing tracers (bromide) as a proxy to assess pesticide (atrazine) transport processes in agricultural soils, the behavior of the three solutes was compared. Because pesticide leaching is governed by drainage, this comparison was performed in terms of breakthrough against accumulated drainage (Fig. 7) for the four combinations of soil type and application method. Most of the discussion is focused on the ability of the tracers to indicate the potential for pesticide leaching by preferential flow. The periods with the most intense irrigation and drainage are highlighted.

With surface application, rapid breakthrough of the three solutes was observed a few hours or days after application within $100 \mathrm{~mm}$ of accumulated drainage in the moraine soil but not in the gravel soil (Fig. 7). Recoveries in the drainage water of the moraine soil lysimeters (L8 and L9) during this early preferential transport ranged from 0.4 to $1.0 \%$ for atrazine, from 0.3 to $0.6 \%$ for bromide, and between 0.1 and $0.4 \%$ for uranine (Fig. 7). The small amount of accumulated drainage needed for uranine and atrazine peaks to occur (Fig. 5) suggests that both solutes were mainly transported through preferential flow, bypassing large fractions of the soil matrix. The pronounced peak tailing for both solutes (Fig. 5) is also typical of preferential flow (Brusseau and Rao, 1990). It is commonly accepted that high precipitation or irrigation shortly after application increases the losses through macropores (Kördel et al., 2008), as was observed in the present experiments. Accordingly, detection of pesticides and non-conservative tracers in leachate within a few hours or days after irrigation has been previously observed at the laboratory and field scales and attributed to preferential flow (Kladivko et al., 1991; Kanwar et al., 1997; Kung et al., 2000; Haws et al., 2004). In the present experiments, the effect was more significant for the moraine than the gravel soil. Probably several dead-end macropores in the moraine soil were formed because the lysimeters were filled up and these macropores were well preserved, at least below $20 \mathrm{~cm}$, where they are not destroyed by tillage practices.

With depth injection, more intense early preferential breakthrough than for surface application was detected for the three solutes within a few days and after $<50 \mathrm{~mm}$ of accumulated drainage (Fig. 7). Early preferential breakthrough occurred in both soil types, although it was more significant for the moraine soil. Recoveries were higher than for surface application: up to 1.0 and $1.8 \%$ for atrazine, up to 1.3 and $1.8 \%$ for bromide, and up to 0.7 and $0.9 \%$ for uranine in the gravel (L3 and L6) and moraine soils (L7 and L10), respectively.

During the early breakthrough, although for the three solutes similar recoveries were measured, uranine was a better marker than bromide for illustrating this preferential transport. In the moraine soil, independent of the application method, both atrazine and uranine broke through during the first intense irrigation; in the gravel soil, both of them were below or close to the detection limit. Uranine always showed the same trend as atrazine when preferential flow occurred (Fig. 7). Furthermore, when atrazine was not detected in the drainage water, uranine was not detected either. Bromide mimicked early preferential atrazine leaching for the moraine soil with depth application but failed for the other combinations of soil type and application method (Fig. 7). In some cases, bromide appeared early but neither atrazine nor uranine was present, suggesting that rapid transport occurred along flow paths with a substantial sorption capacity. Only between 0.1 and $2.5 \%$ of the total mass of bromide accumulating in the drainage water was recovered during the early preferential breakthrough, whereas for uranine and atrazine this fraction ranged from 11 to $88 \%$.

After the early breakthrough, the two tracers-uranine and bromine-continued to show a contrasting behavior. Bromide breakthrough curves showed a characteristic asymmetric sigmoidal shape for transport through a porous matrix irrespective of surface or depth injection (Fig. 7). For both application methods, bromide breakthrough in the gravel soil was higher and was achieved more rapidly than in the moraine soil in accordance with the lower water retention capacity of the former (Fig. 7). In stark contrast, the uranine recovery did not increase any more. In contrast to bromide, the smoother breakthrough curves of atrazine suggest that atrazine transport through the soil matrix was retarded by sorption and attenuated by degradation. A steady increment in accumulated mass recovery was observed for atrazine and bromide but not for uranine (Fig. 7). Retardation was, therefore, more significant for uranine than for atrazine, especially for surface 
application. Sabatini and Austin (1991) compared the sorption of atrazine and uranine in an alluvial sand with a low organic matter content in laboratory experiments and found similar sorption coefficient values ( $K_{\text {oc }}$ of $120 \mathrm{~cm}^{3} \mathrm{~g}^{-1}$ for uranine and $148 \mathrm{~cm}^{3}$ $\mathrm{g}^{-1}$ for atrazine), although different sorption mechanisms were proposed. Sorption of uranine, because of its high polarity and ionizable nature, is dominated by electrostatic rather than hydrophobic interactions and thus is more dependent on mineralogy than organic content. Uranine shows higher sorption to positively charged surfaces such as limestones or carbonates at neutral $\mathrm{pH}$ (Kasnavia et al., 1999). This different sorption mechanism might be the cause of the different atrazine and uranine retardation observed in the present experiments.

The DEA/atrazine molar ratio (DAR) is often used as a proxy for atrazine degradation in the environment (Adams and Thurmann, 1991). With surface application, higher DAR values were measured for the gravel (up to 49) than the moraine soil (up to 7) during the first $340 \mathrm{~d}$ (Supplemental Fig. S5), suggesting that the extent of atrazine degradation was higher for the gravel soil or that DEA moved more rapidly through the soil matrix because of higher permeability. This difference in DAR values is consistent with the greater contribution of preferential flow in the moraine soil, which bypasses the top layer where degradation mostly takes place. During the first $340 \mathrm{~d}$, lower DAR values were measured for depth injection than for surface application (up to 1 for the gravel and up to 4 for the moraine soil). Because by depth injection the atrazine molecules were emplaced deeper, they persisted longer in the soil matrix and slower degradation occurred. Similarly, Kruger et al. (1997) found that atrazine application in subsurface soils $(90-120 \mathrm{~cm})$ compared with surface soils $(0-30 \mathrm{~cm})$ resulted in greater persistence and more mobility during the subsequent drainage periods. Similar results were obtained by Delphin and Chapot (2006) for atrazine injection at different depths $(30$ and $80 \mathrm{~cm})$. The maximum depth of macropores might therefore have a significant effect on the persistence and mobility of the applied pesticides. Deeper macropores would result in high pesticide mass fluxes to shallow groundwater. The results of the present experiments show that degradation of atrazine occurred not only in the microbiologically active topsoil but also deeper in the soil profile because DEA was also detected in the drainage water of the lysimeters in which atrazine was injected at $40 \mathrm{~cm}$.

The heavy irrigation performed $340 \mathrm{~d}$ after solute application promoted leaching of atrazine and DEA molecules that were retained in the soil matrix for both surface (Fig. 5) and depth applications (Fig. 6). Between 0.1 and $0.8 \%$ of the atrazine applied mass was recovered during this May 2015 breakthrough, whereas this fraction corresponded to 20 to $30 \%$ of the applied bromide. Whereas no changes were observed in the sigmoidal shape of the bromide curves, sharp recovery increases were detected for atrazine at this time (Fig. 7). Atrazine leaching during this breakthrough appeared to be of slightly higher significance in the gravel than the moraine soil (Fig. 7). For bromide, transport occurred mainly through the matrix in the two soils, whereas atrazine leaching was dominated by large drainage events when a greater contribution of preferential flow probably occurred.

Uranine concentration in the drainage water was monitored only during the first $330 \mathrm{~d}$ after application. A second uranine application was performed at this time. Although not included here, the results suggest rapid uranine arrival after application, coinciding in time with the May 2015 atrazine peak. Although most of the leached mass is expected to be related to the second application, the contribution of the uranine applied in 2014 cannot be excluded. The suitability of uranine for mimicking the second atrazine breakthrough was therefore not evaluated.

\section{Conclusions}

Evaluation of pesticide transport through arable soils using dye tracers has been done so far at the laboratory scale (e.g., Sabatini and Austin, 1991) or with tile-drainage plots (e.g., Czapar et al., 1994) but not with large lysimeters. Large lysimeters are more likely to mimic natural soils than laboratory column experiments. Furthermore, greater control over environmental factors and more precise solute mass balances are achieved with lysimeters than with drainage plots. Using large lysimeters, we demonstrated that uranine is a more realistic marker than bromide for early atrazine preferential breakthrough shortly after pesticide application. Uranine broke through during the first intense irrigation event at the same time as atrazine. Bromide, however, appeared in some cases earlier than atrazine.

The rapid preferential atrazine breakthrough was more significant for the moraine than the gravel soil and, as expected, more evident after depth injection. In the moraine soil, more macropores were probably formed with time and were better preserved because of the clayey matrix. The high soil water content present before atrazine application, the heavy irrigation applied just after, and the low ET promoted preferential flow. This movement bypassed large fractions of the soil matrix, reducing the degradation and sorption potential, and therefore high atrazine and low DEA contents were detected in the drainage water. During the slow atrazine transport by matrix flow, the concentration in the drainage water was higher for the lysimeters with depth injection, as expected for the deeper starting point of migration. Atrazine and uranine concentrations during leaching via matrix flow were greatly reduced by sorption and degradation. The detection of DEA in the drainage water confirmed herbicide degradation, although sorption to the soil particles was probably the main retardation factor in atrazine transport. Atrazine leaching was driven by large drainage events, when a greater contribution of preferential flow probably occurred. As a consequence, another atrazine breakthrough peak occurred 10 mo after application. 
For both surface and depth application approaches, bromide was transported by both matrix and preferential flow. However, because preferential flow accounts for only a small fraction of water flow, the bromide breakthrough curve was dominated by the matrix flow component. In contrast, atrazine and uranine are retained or degraded in the matrix, and leaching was dominated by large drainage events when preferential flow occurs.

In the present experiments, uranine was a reliable marker for atrazine breakthrough shortly after atrazine application. Atrazine represents a realistic worst case of pesticide leaching because of its moderate mobility and relatively low adsorption coefficient. For extending the use of sorbing dye tracers as a surrogate of other pesticides, tracers with similar mobility as the target compound should be chosen.

Overall, these results point to the potential use of uranine as a surrogate of atrazine for preferential leaching shortly after application. Uranine also may be a valuable tool for evaluating the potential of preferential flow in different soil types. Uranine application may therefore be used for rapid screening of the possibility of inducing preferential flow in a given soil. Application of uranine might also help to delimit the threshold range of soil water content, rain amount, and intensity that induces a given degree of early preferential flow. The application of dye tracers at the same time as the pesticides may also be used as a low-cost approach in pesticide risk studies and thus applying measures to limit irrigation and potential threats to groundwater-however, only for assessing rapid pesticide leaching by preferential flow. The use of dye tracers as pesticide surrogates might assist in making sustainable decisions with respect to pesticide application timing relative to rainfall, application method, or rainfall or irrigation regime.

\section{Supplemental Material}

The supplemental material includes pictures of the Agroscope lysimeters facility, water balance components for Lysimeter L4, evapotranspiration and air temperature data, DAR trends, results for the first $375 \mathrm{~d}$ after application or injection, and average monthly sums of the water-balance components from the two soil types.

\section{Acknowledgments}

This study was supported by the project CRSII2_141805/1 from the Swiss National Science Foundation (SNSF). We are grateful to Clay Humphrys and Karin Meier Zimmermann (Agroscope) for technical assistance with field work on the lysimeter facility. We also want to thank the Plateforme neuchâteloise de chimie analytique (NPAC) for their services and Vincent Gruber, Roberto Costa, and Laurent Marguet (University of Neuchâtel) for their help during the setting up and monitoring of the lysimeter experiments. We thank the associate editor (Dr. Markus Flury) and three anonymous reviewers for comments that improved the quality of the manuscript.

\section{References}

Abdou, H.M., and M. Flury. 2004. Simulation of water flow and solute transport in free-drainage lysimeters and field soils with heterogeneous structures. Eur. J. Soil Sci. 55:229-241. doi:10.1046/j.1365-2389.2004.00592.x

Adams, C.D., and E.M. Thurmann. 1991. Formation and transport of deethylatrazine in the soil and vadose zone. J. Environ. Qual. 20:540 547. doi:10.2134/jeq1991.00472425002000030007x

Albisser, C., and V. Prasuhn. 2013. Auswirkungen des Klimawandels auf die Schadstoffverfrachtung ins Grundwasser: Projekt-Schlussbericht
Studie im Auftrag des BAFU. Publ. Forschungsanstalt Agroscope Reckenholz-Tänikon ART, Zürich.

Barraclough, D., T. Kearney, and A. Croxford. 2005. Bound residues: Environmental solution or future problem? Environ. Pollut. 133:85-90. doi:10.1016/j.envpol.2004.04.016

Bech, T.B., A.E. Rosenbom, S.R. Sørensen, and C.S. Jacobsen. 2017. Conservative tracer bromide inhibits pesticide mineralisation in soil. Environ. Pollut. 222:404-411. doi:10.1016/j.envpol.2016.12.016

Bergström, L. 1990. Use of lysimeters to estimate leaching of pesticides in agricultural soils. Environ. Pollut. 67:325-347. doi:10.1016/02697491 (90)90070-S

Bergström, L. 2000. Leaching of agrochemicals in field lysimeters: A method to test mobility of chemicals in soil. In: J. Cornejo et al., editors, Pesticide/ soil interactions: Some current research methods. INRA, Paris.

Beven, K., and P. Germann. 1982. Macropores and water flow in soils. Water Resour. Res. 18:1311-1325. doi:10.1029/WR018i005p01311

Beven, K., and P. Germann. 2013. Macropores and water flow in soils revisited. Water Resour. Res. 49:3071-3092. doi:10.1002/wrcr.20156

Boesten, J.J.T.I. 2007. Simulation of pesticide leaching in the field and in zerotension lysimeters. Vadose Zone J. 6:793-804. doi:10.2136/vzj2007.0067

Bouma, J., and L.W. Dekker. 1978. A case study on infiltration into dry clay soil: I. Morphological observations. Geoderma 20:27-40. doi:10.1016/0016-7061 (78)90047-2

Bowman, B.T. 1990. Mobility and persistence of alachlor, atrazine and metolachlor in Plainfield sand, and atrazine and isazofos in Honeywood silt loam using field lysimeters. Environ. Toxicol. Chem. 9:453-461. doi:10.1002/etc.5620090406

Brown, C.D., J.M. Hollis, R.J. Bettinson, and A. Walker. 2000. Leaching of pesticides and a bromide tracer through lysimeters from five contrasting soils. Pest Manage. Sci. 56:83-93. doi:10.1002/(SICI) 15264998(200001)56:1<83::AID-PS98>3.0.CO;2-8

Brusseau, M.L., and P.S.C. Rao. 1990. Modeling solute transport in structured soils: A review. Geoderma 46:169-192. doi:10.1016/00167061 (90)90014-Z

Burnett, G., K. Balu, H. Barton, W. Chen, B. Gold, P. Hertl, et al. 2000. Summary of environmental fate of atrazine. Study No. 1213-99. Novartis Crop Protection, Greensboro, NC.

Calderbank, A. 1989. The occurrence and significance of bound pesticide residues in soil. Rev. Environ. Contam. Toxicol. 108:71-103. doi:10.1007/978-1-4613-8850-0_2

Capriel, P., A. Haisch, and S.U. Khan. 1985. Distribution and nature of bound (nonextractable) residues of atrazine in a mineral soil nine years after the herbicide application. J. Agric. Food Chem. 33:567569. doi:10.1021/jf00064a004

Cey, E.E., and D.L. Rudolph. 2009. Field study of macropore flow processes using tension infiltration of a dye tracer in partially saturated soils. Hydrol. Processes 23:1768-1779. doi:10.1002/hyp.7302

Czapar, G.F., R.S. Kanwar, and R.S. Fawcett. 1994. Herbicide and tracer movement to field drainage tiles under simulated rainfall conditions. Soil Tillage Res. 30:19-32. doi:10.1016/0167-1987(94)90148-1

D'Archivio, A.A., M. Fanelli, P. Mazzeo, and F. Ruggieri. 2007. Comparison of different sorbents for multiresidue solid-phase extraction of 16 pesticides from groundwater coupled with high-performance liquid chromatography. Talanta 71:25-30. doi:10.1016/j.talanta.2006.03.016

Delphin, J.E., and J.Y. Chapot. 2006. Leaching of atrazine, metolachlor and diuron in the field in relation to their injection depth into a silt loam soil. Chemosphere 64:1862-1869. doi:10.1016/j.chemosphere.2006.01.049

Dousset, S., M. Babut, F. Andreux, and M. Schiavon. 2004. Alachlor and bentazone losses from subsurface drainage of two soils. J. Environ. Qual. 33:294-301. doi:10.2134/jeq2004.2940

Dousset, S., C. Mouvet, and M. Schiavon. 1995. Leaching of atrazine and some of its metabolites in undisturbed field lysimeters of three soil types. Chemosphere 30:51 1-524. doi:10.1016/0045-6535(94)00414-P

Edwards, W.M., M.J. Shipitalo, W.A. Dick, and L.B. Owens. 1992. Rainfall intensity affects transport of water and chemicals through macropores in no-till soil. Soil Sci. Soc. Am. J. 56:52-58. doi:10.2136/sssaj1992.03615995005600010008x

Everts, C.J., and R.S. Kanwar. 1990. Estimating preferential flow to a subsurface drain with tracers. Trans. ASAE 33:451-457. doi: $10.13031 / 2013.31350$

Everts, C.J., and R.S. Kanwar. 1994. Evaluation of Rhodamine WT as an adsorbed tracer in an agricultural soil. J. Hydrol. 153:53-70. doi:10.1016/0022-1694(94)90186-4

Everts, C.J., R.S. Kanwar, E.C. Alexander, and S.C. Alexander. 1989. 
Comparison of tracer mobilities under laboratory and field conditions. J. Environ. Qual. 18:491-498. doi:10.2134/jeq1989.00472425001800040018x

Fank, J. 2009. Tracerhydrologie in der Lysimetrie. In: 13th Gumpensteiner Lysimetertagung zum Thema Lysimeter: Perspektiven in Forschung und Anwendung, Raumberg. 21-22 Apr. 2009. Höhere Bundeslehr und Forschungsanstalt für Landwirtschaft, Raumberg, Austria. p. 63-68.

Fenner, K., S. Canonica, L.P. Wackett, and M. Elsner. 2013. Evaluating pesticide degradation in the environment: Blind spots and emerging opportunities. Science 341:752-758. doi:10.1126/science.1236281

Flury, M., H. Flühler, W.A. Jury, and J. Leuenberger. 1994. Susceptibility of soils to preferential flow of water: A field study. Water Resour. Res. 30:1945-1954. doi:10.1029/94WR00871

Flury, M., and N.N. Wai. 2003. Dyes as tracers for vadose zone hydrology. Rev. Geophys. 41:1002. doi:10.1029/2001RG000109

Flury, M., M.V. Yates, and W.A. Jury. 1999. Numerical analysis of the effect of the lower boundary condition on solute transport in lysimeters. Soil Sci. Soc. Am. J. 63:1493-1499. doi:10.2136/sssaj1999.6361493x

Fortin, J., E. Gagnon-Bertrand, L. Vézina, and M. Rompré. 2002. Preferential bromide and pesticide movement to tile drains under different cropping practices. J. Environ. Qual. 31:1940-1952. doi:10.2134/jeq2002.1940

Francaviglia, R., and E. Capri. 2000. Lysimeter experiments with metolachlor in Tor Mancina (Italy). Agric. Water Manage. 44:63-74. doi:10.1016/S0378-3774(99)00084-0

Gevao, B., K.T. Semple, and K.C. Jones. 2000. Bound pesticide residues in soils: A review. Environ. Pollut. 108:3-14. doi:10.1016/S0269 7491 (99)00197-9

Greve, A., M.S. Andersen, and R.I. Acworth. 2010. Investigations of soil cracking and preferential flowin a weighing lysimeterfilled with cracking clay soil. J. Hydrol. 393:105-1 13. doi:10.1016/j.jhydrol.2010.03.007

Hall, J.K., R.O. Mumma, and D.W. Watts. 1991. Leaching and runoff losses of herbicides in a tilled and untilled field. Agric. Ecosyst. Environ. 37:303-314. doi:10.1016/0167-8809(91)90158-T

Hannes, M., U. Wollschläger, F. Schrader, W. Durner, S. Gebler, T. Pütz, et al. 2015. A comprehensive filtering scheme for high-resolution estimation of the water balance components from high-precision lysimeters. Hydrol. Earth Syst. Sci. 19:3405-3418. doi:10.5194/hess-19-3405-2015

Hardie, M., W.E. Cotching, R.B. Doyle, G. Holz, S. Lisson, and K. Mattern. 2011. Effect of antecedent soil moisture on preferential flow in a texturecontrast soil. J. Hydrol. 398:191-201. doi:10.1016/j.jhydrol.2010.12.008

Haws, N.W., B.S. Das, and P.S.C. Rao. 2004. Dual-domain solute transfer and transport processes: Evaluation in batch and transport experiments. J. Contam. Hydrol. 75:257-280. doi:10.1016/j.jconhyd.2004.07.001

Jablonowski, N.D., S. Köppchen, D. Hofmann, A. Schäffer, and P. Buravel. 2009. Persistence of ${ }^{14} \mathrm{C}$-labeled atrazine and its residues in a field lysimeter soil after 22 years. Environ. Pollut. 157:21262131. doi:10.1016/j.envpol.2009.02.004

Jablonowski, N.D., A.Linden,S.Köppchen, B.Thiele, D. Hofmann, W. Mittelstaedt, et al. 2012. Long-term persistence of various ${ }^{14} \mathrm{C}$-labeled pesticides in soils. Environ. Pollut. 168:29-36. doi:10.1016/j.envpol.2012.04.022

Jablonowski, N.D., J. Modler, A. Schaeffer, and P. Burauel. 2008 Bioaccessibility of environmentally aged ${ }^{14} \mathrm{C}$-atrazine residues in an agriculturally used soil and its particle-size aggregates. Environ. Sci. Technol. 42:5904-5910. doi:10.1021/es800196z

Jacobsen, O.H., and J. Kjaer. 2007. Is tile drainage water representative of root zone leaching of pesticides? Pest Manage. Sci. 63:417-428. doi:10.1002/ps.1372

Jarvis, N.J. 2007. A review of non-equilibrium water flow and solute transport in soil macropores: Principles, controlling factors and consequences for water quality. Eur. J. Soil Sci. 58:523-546. doi:10.1111/j.1365-2389.2007.00915.x

Jaynes, D.B., S.I. Ahmed, and K.-J.S. Kung. 2001. Temporal dynamics of preferential flow to a subsurface drain. Soil Sci. Soc. Am. J. 65:13681376. doi:10.2136/sssaj2001.6551368x

Kanwar, R.S., J.L. Baker, and P. Singh. 1997. Use of chloride and fluorescent dye as tracers in measuring nitrate and atrazine transport through soil profile under laboratory conditions. J. Environ. Sci. Health A 32:19071919. doi:10.1080/10934529709376654

Kasnavia, T., D. Vu, and D.A. Sabatini. 1999. Fluorescent dye and media properties affecting sorption and tracer selection. Ground Water 37:376-381. doi:10.1111/j.1745-6584.1999.tb01114.x

Kasteel, R., M. Burkhardt, S. Giesa, and H. Vereecken. 2005. Characterization of field tracer transport using high-resolution images. Vadose Zone J. 4:101-111. doi:10.2113/4.1.101

Kasteel, R., T. Pütz, J. Vanderborght, and H. Vereecken. 2010. Fate of two herbicides in zero-tension lysimeters and in field soil. J. Environ. Qual. 39:1451-1466. doi:10.2134/jeq2009.0236

Kasteel, R., T. Pütz, and H. Vereecken. 2007. An experimental and numerical study on flow and transport in a field soil using zerotension lysimeters and suction plates. Eur. J. Soil Sci. 58:632-645. doi:10.1111/j.1365-2389.2006.00850.x

Kladivko, E.J., G.E. Van Scoyoc, E.J. Monke, K.M. Oates, and W. Pask. 1991. Pesticide and nutrient movement into subsurface tile drains on a silt loam soil in Indiana. J. Environ. Qual. 20:264-270. doi:10.2134/jeq1991.00472425002000010043x

Kodešová, R., K. Němeček, V. Kodeš, and A. Žigová. 2012. Using dye tracer for visualization of preferential flow at macro- and microscales. Vadose Zone J. 11(1). doi:10.2136/vzj2011.0088

Kolpin, D.W., E.M. Thurman, and S.M. Linhart. 1998. The environmental occurrence of herbicides: The importance of degradates in ground water. Arch. Environ. Contam. Toxicol. 35:385-390. doi:10.1007/s002449900392

Kolpin, D.W., E.M. Thurman, and S.M. Linhart. 2000. Finding minimal herbicide concentrations in ground water? Try looking for their degradates. Sci. Total Environ. 248:115-122. doi:10.1016/S0048-9697(99)00535-5

Kördel, W., H. Egli, and M. Klein. 2008. Transport of pesticides via macropores (IUPAC Technical Report). Pure Appl. Chem. 80:105-160. doi:10.1351/pac200880010105

Kung, K.-J.S., T.S. Steenhuis, E.J. Kladivko, T.J. Gish, G. Bubenzer, and C.S. Helling. 2000. Impact of preferential flow on the transport of adsorbing and non-adsorbing tracers. Soil Sci. Soc. Am. J. 64:12901296. doi:10.2136/sssaj2000.6441290x

Kruger, E.L., P.J. Rice, J.C. Anhalt, T.A. Anderson, and J.R. Coats. 1997. Comparative fates of atrazine and deethylatrazine in sterile and nonsterile soils. J. Environ. Qual. 26:95-101. doi:10.2134/jeq1997.00472425002600010015x

Lange, J., T. Schuetz, C. Gregoire, D. Elsässer, R. Schulz, E. Passeport, and J. Tournebize. 201 1. Multi-tracerexperiments to characterize contaminant mitigation capacities for different types of artificial wetlands. Int. J. Environ. Anal. Chem. 91:768-785. doi:10.1080/03067319.2010.525635

Leistra, M., and J.J.T.I. Boesten. 1989. Pesticide contamination of groundwater in Western Europe. Agric. Ecosyst. Environ. 26:369-389. doi:10.1016/0167-8809(89)90018-2

Lennartz,B., J.Michaelsen,P.Widmoser, andW.Wichtmann. 1999.Timevariance analysis of preferential solute movement at a tile-drained field site. Soil Sci. Soc. Am. J. 63:39-47. doi:10.2136/sssaj1999.03615995006300010007x

Lewis, K.A., J. Tzilivakis, D. Warner, and A. Green. 2016. An international database for pesticide risk assessments and management. Hum. Ecol. Risk Assess. 22:1050-1064. doi:10.1080/10807039.2015.1133242

Loos, R., G. Locoro, S. Comero, S. Contini, D. Schwesig, F. Werres, et al. 2010. Pan-European survey on the occurrence of selected polar organic persistent pollutants in ground water. Water Res. 44:41154126. doi:10.1016/j.watres.2010.05.032

Lopez, B., P. Ollivier, A. Togola, N. Baran, and J.P. Ghestem. 2015. Screening of French groundwater for regulated and emerging contaminants. Sci. Total Environ. 518-519:562-573. doi:10.1016/j.scitotenv.2015.01.110

Maillard, E., J. Lange, S. Schreiber, J. Dollinger, B. Herbstritt, M. Millet, and G. Imfeld. 2016. Dissipation of hydrological tracers and the herbicide S-metolachlor in batch and continuous-flow wetlands. Chemosphere 144:2489-2496. doi:10.1016/j.chemosphere.2015.11.027

Masse, L., N.K. Patni, P.Y. Jui, and B.S. Clegg. 1996. Tile effluent quality and chemical losses under conventional and no tillage: 2 . Atrazine and metolachlor. Trans. ASAE 39:1673-1679. doi:10.13031/2013.27684

McGrath, G.S., C. Hinz, M. Sivapalan, J. Dressel, T. Pütz, and H. Vereecken. 2010. Identifying a rainfall event threshold triggering herbicide leaching by preferential flow. Water Resour. Res. 46:W02513. doi:10.1029/2008WR007506

Mendaš, G., V. Drevenkar, and L. Zupancic-Kralj. 2001. Solidphase extraction with styrene-divinylbenzene sorbent for highperformance liquid or gas chromatographic determination of urinary chloro- and methylthiotriazines. J. Chromatogr. A 918:351-359. doi:10.1016/S0021-9673(01)00768-3

Meyer, A.H., and M. Elsner. 2013. ${ }^{13} \mathrm{C} /{ }^{12} \mathrm{C}$ and ${ }^{15} \mathrm{~N} /{ }^{14} \mathrm{~N}$ isotope analysis to characterize degradation of atrazine: Evidence from parent and daughter compound values. Environ. Sci. Technol. 47:6884-6891. doi:10.1021/es305242q

Mudhoo, A., and V.K. Garg. 2011. Sorption, transport and transformation of atrazine in soils, minerals and composts: A review. Pedosphere 21:11-25. doi:10.1016/S1002-0160(10)60074-4

Nievergelt, J. 1997. Lysimeterversuch 1981 bis 1996: N-Auswaschung in Fruchtfolgen. Agrarforschung 4:209-212. 
Nimmo, J.R. 2007. Simple predictions of maximum transport rate in unsaturated soil and rock. Water Resour. Res. 43:W05426. doi:10.1029/2006WR005372

Passeport, E., J. Tournebize, S. Jankowsky, B. Prömse, C. Chaumont, Y. Coquet, and J. Lange. 2010. Artificial wetland and forest buffer zone: Hydraulic and tracer characterization. Vadose Zone J. 9:73-84 doi:10.2136/vzj2008.0164

Peters, A., T. Nehls, H. Schonsky, and G. Wessolek. 2014. Separating precipitation and evapotranspiration from noise: A new filter routine for high-resolution lysimeter data. Hydrol. Earth Syst. Sci. 18:1 189-1198. doi:10.5194/hess-18-1189-2014

Pichon, V., C.C.D. Coumes, L. Chen, S. Guenu, and M.C. Hennion 1996. Simple removal of humic and fulvic acid interferences using polymeric sorbents for the simultaneous solid-phase extraction of polar acidic, neutral and basic pesticides. J. Chromatogr. A 737:2533. doi:10.1016/0021-9673(95)01339-3

Prasuhn, V., E. Spiess, and C. Humphrys. 2015. Tracerversuche mit Bromid auf verschiedenen Lysimetern in der Schweiz. In: 16th Gumpensteiner Lysimetertagung zum Thema Lysimeter: Forschung im System BodenPflanze-Atmosphäre, Raumberg, Austria. 21-22. Apr. 2015. Höhere Bundeslehr- und Forschungsanstalt, Irdning-Stainach, Austria. p. 21-28.

Renaud, F.G., C.D. Brown, C.J. Fryer, and A. Walker. 2004. A lysimeter experiment to investigate temporal changes in the availability of pesticide residues for leaching. Environ. Pollut. 131:81-91. doi:10.1016/j.envpol.2004.02.028

Roeth, F.W., and T.L. Lavy. 1971. Atrazine uptake by sudangrass, sorghum and corn. Weed Sci. 19:93-97. doi:10.1017/S0043174500048372

Sabatini, D.A., and T. Austin. 1991. Characteristics of rhodamine WT and fluorescein as adsorbing ground-water tracers. Ground Water 29:341349. doi:10.1111/j.1745-6584.1991.tb00524.x

Schuhmann, A., O. Gans, S. Weiss, J. Fank, G. Klammler, G. Haberhaver and M.H. Gerzabek. 2016. A long-term lysimeter experiment to investigate the environmental dispersion of the herbicide chloridazon and its metabolites: Comparison of lysimeter types. J. Soils Sediments 16:1032-1045. doi:10.1007/s11368-015-1311-3

Steinheimer, T.R., and K.D. Scoggin. 2001. Fate and movement of atrazine, cyanazine, metolachlor and selected degradation products in water resources of the deep loess hills of southwestern lowa, USA. J. Environ. Monit. 3:126-132. doi:10.1039/B006871N

Suter, D. E. Rosenberg, E. Mosimann, and R. Frick. 2012. Standardmischungen für den Futterbau. Revision 2013-2016. Agrarforsch. Schweiz 3:1-12.

Syngenta. 2005. Using atrazine and protecting water quality: A guide for corn/sorghum producers and sugarcane growers. GS 405.00001. Syngenta Crop Protection, Greensboro, NC.

Troxler, J., M. Zala, A. Natsch, J. Nievergelt, C. Keel, and G. Défago. 1998 Transport of a biocontrol Pseudomonas fluorescens through 2.5-m deep outdoor lysimeters and survival in the effluent water. Soil Biol. Biochem. 30:621-631. doi:10.1016/S0038-0717(97)00158-2

Vereecken, $H_{\text {., }}$ and M. Dust. 1998. Modelling water flow and pesticide transport at lysimeter and field scale. ACS Symp. Ser. 699:189-202. doi:10.1021/bk-1998-0699.ch014

Vink, J.P.M., B. Gottesbüren, B. Diekkrüger, and S. Van der Zee. 1997. Simulation and model comparison of unsaturated movement of pesticides from a large clay lysimeter. Ecol. Modell. 105:113-127. doi:10.1016/S0304-3800(97)00147-6

Vonberg, D., D. Hofmann, J. Vanderborght, A. Lelickens, S. Köppchen, T. Pütz, P. Burauel, and H. Vereecken. 2014. Atrazine soil core residue analysis from an agricultural field 21 years after its ban. J. Environ. Qual. 50:294-306. doi:10.2134/jeq2013.12.0497

Wang, K., and R. Zhang. 2011. Heterogeneous soil water flow and macropores described with combined tracers of dye and iodine. J. Hydrol. 397:105-117. doi:10.1016/j.jhydrol.2010.11.037

Wauchope, R.D., S. Yeh, J.B.J.H. Linders, R.R. Kloskowski, K. Tanaka B. Rubin, et al. 2002. Pesticide soil sorption parameters: Theory measurement, uses, limitations and reliability. Pest Manage. Sci. 58:419-445. doi:10.1002/ps.489

Weigel, S., K. Bester, and H. Hühnerfuss. 2001. New method for rapid solidphase extraction of large-volume water samples and its application to non-target screening of North Sea water for organic contaminants by gas chromatography-mass spectrometry. J. Chromatogr. A 912:151-161. doi:10.1016/S0021-9673(01)00529-5 